\title{
Crustal structure of the Java margin from seismic wide-angle and multichannel reflection data
}

\author{
Heidrun Kopp, Dirk Klaeschen, Ernst R. Flueh, and Jörg Bialas \\ GEOMAR Research Center for Marine Geosciences, Kiel, Germany \\ Christian Reichert \\ Federal Institute for Geosciences and Natural Resources, Hannover, Germany
}

Received 11 December 2000; revised 25 September 2001; accepted 2 October 2001; Published 14 February 2002

[1] Seismic investigations across the convergent Sunda margin off Indonesia provide a detailed image of the crustal architecture of the Sunda plate boundary. The combined analysis and interpretation of wide-angle and reflection seismic data along two coincident profiles across the subduction zone are complemented by additional lines within the forearc domain, which yield some three-dimensional (3-D) constraints on the velocity-depth structure across the margin. A detailed cross section of the subduction zone is presented, which is confirmed by supplementary gravity modeling. The Sunda convergence zone is a prime example of an accretionary margin, where sediment accretion has led to the formation of a massive accretionary prism, with a total width of $>110 \mathrm{~km}$ between the trench and the forearc basin. It is composed of a frontal wedge which documents ongoing accretion and a fossil part behind the present backstop structure which constitutes the outer high. Moderate seismic velocities derived from wide-angle modeling indicate a sedimentary composition of the outer high. The subducting oceanic slab is traced to a depth of almost $30 \mathrm{~km}$ underneath the accretionary prism. The adjacent forearc domain is characterized by a pronounced morphological basin which is underlain by a layer of increased seismic velocities and a shallow upper plate Moho at $16 \mathrm{~km}$ depth. We speculate that remnant fragments of oceanic crust might be involved in the formation of this oceanic-type crust found at the leading edge of the upper plate beneath the forearc basin. INDEX TERMS: 3025 Marine Geology and Geophysics: Marine seismics (0935); 8015 Structural Geology: Local crustal structure; 8122 Tectonophysics: Dynamics, gravity and tectonics; 1219 Geodesy and Gravity: Local gravity anomalies and crustal structure; KEYWORDS: Sunda subduction zone, Java margin, accretionary tectonics, forearc structure, seismic reflection, seismic refraction

\section{Introduction}

[2] The Sunda Arc off Indonesia is a classic convergent margin that has acted as a type example for many concepts concerning mechanisms of sediment accretion and forearc evolution [Hamilton, 1979; Karig et al., 1980; Huchon and Le Pichon, 1984; McCaffrey, 1992; Izart et al., 1994; Malod and Kemal, 1996; Samuel and Harbury, 1996]. Several geological parameters, including the curvature of the trench and the age of the subducted plate, change significantly along strike of the margin, thus uniquely placing it in a variety of tectonic settings. The Sunda Arc forms the southern border of the Indonesian Archipelago, where the IndoAustralian plate is subducted beneath Eurasia (Figure 1). Along the arc, the collision system changes from oceanic-continental in Sumatra through transitional in Java to intra-oceanic in Bali and Flores [Hamilton, 1988]. Despite the long history of scientific investigations along the Sunda Arc, only few limited data exist off Java. To fill this gap, the Geo-scientific Investigations along the active Convergence zone between the eastern Eurasian and IndoAustralian Plates off Indonesia (GINCO) Project set out to investigate the crustal structure and plate boundary off Java. Using the R/V Sonneduring November 1998 through January 1999, multichannel seismic reflection (MCS) and wide-angle refraction data were collected across the Sunda subduction zone and forearc domain. In this paper, we report on a coincident MCS/wide-angle seismic profile and two strike lines from the Java margin. These data enable us to track the downgoing plate from the trench to a depth of $30 \mathrm{~km}$ and to derive a velocity-depth model across the subduction complex. Additionally, the structure of the Java margin is resolved in considerable detail. On the basis of these newly acquired seismic data and their interpretation we discuss the crustal structure of the collision zone and present gravity modeling to verify the conclusions.

\section{Geodynamic Setting}

[3] The study area is located off western Java across the Sunda collision zone (Figures 1 and 2). The margin represents a typical subduction zone, displaying the outer bulge and a deep trench. The large accretionary prism is composed of the frontal wedge (the active accretionary domain) and the outer high (the fossil accretionary domain), which are separated by a trench slope break. A forearc basin is found adjacent to a volcanic arc farther in the hinterland. This sector of the Indo-Australian/Eurasian subduction system has been active since at least the Oligocene and evolved after the late Eocene collision of India with Asia [Hamilton, 1988]. This collision resulted in a $10^{\circ}$ clockwise rotation of southeast Asia accompanied by widespread extension and basin formation in the Indonesian region [Rangin et al., 1990; Daly et al., 1991]. The present plate convergence off western Java and the kinematics of the area are well determined by GPS measurements [Tregoning et 


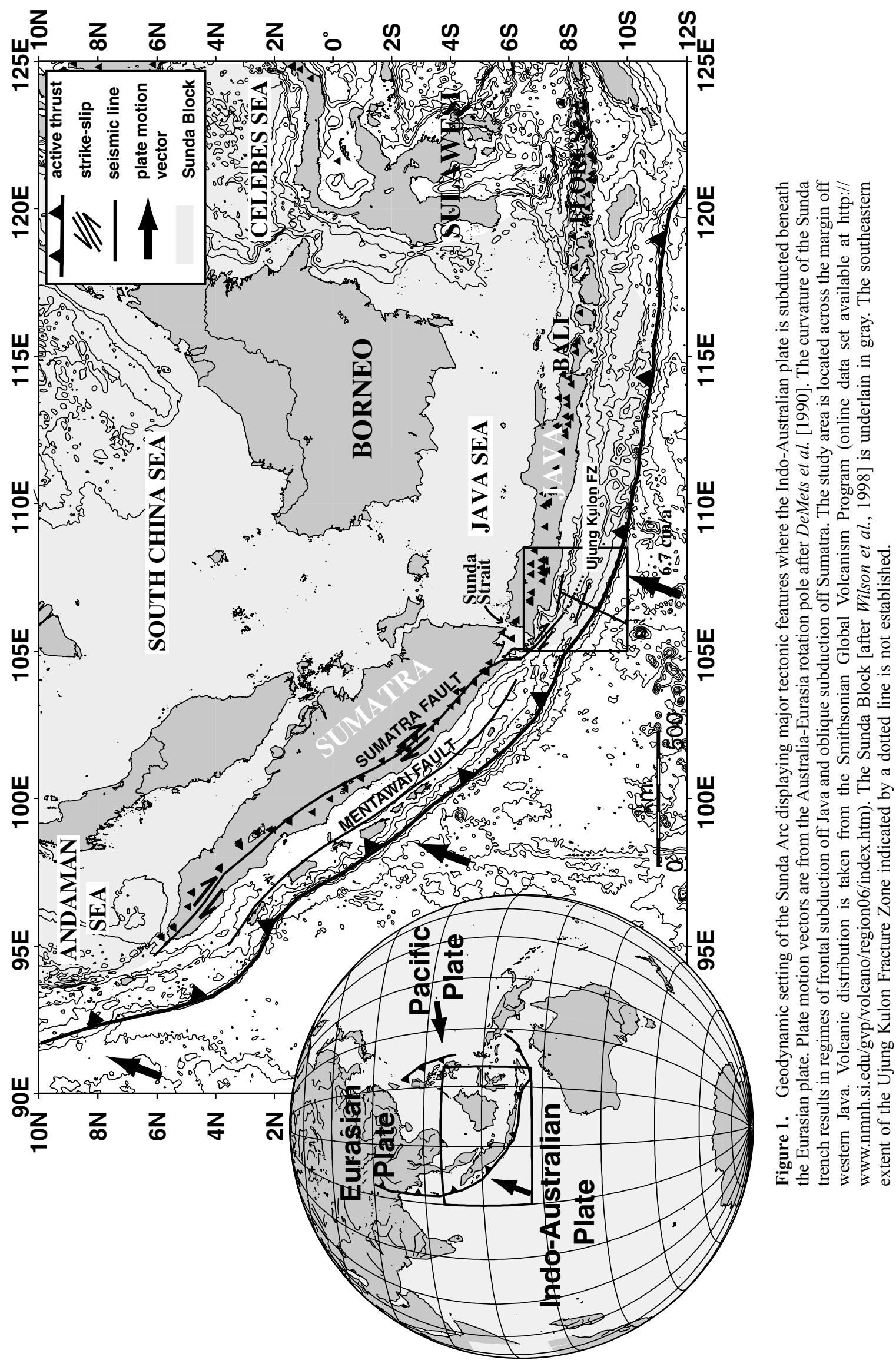




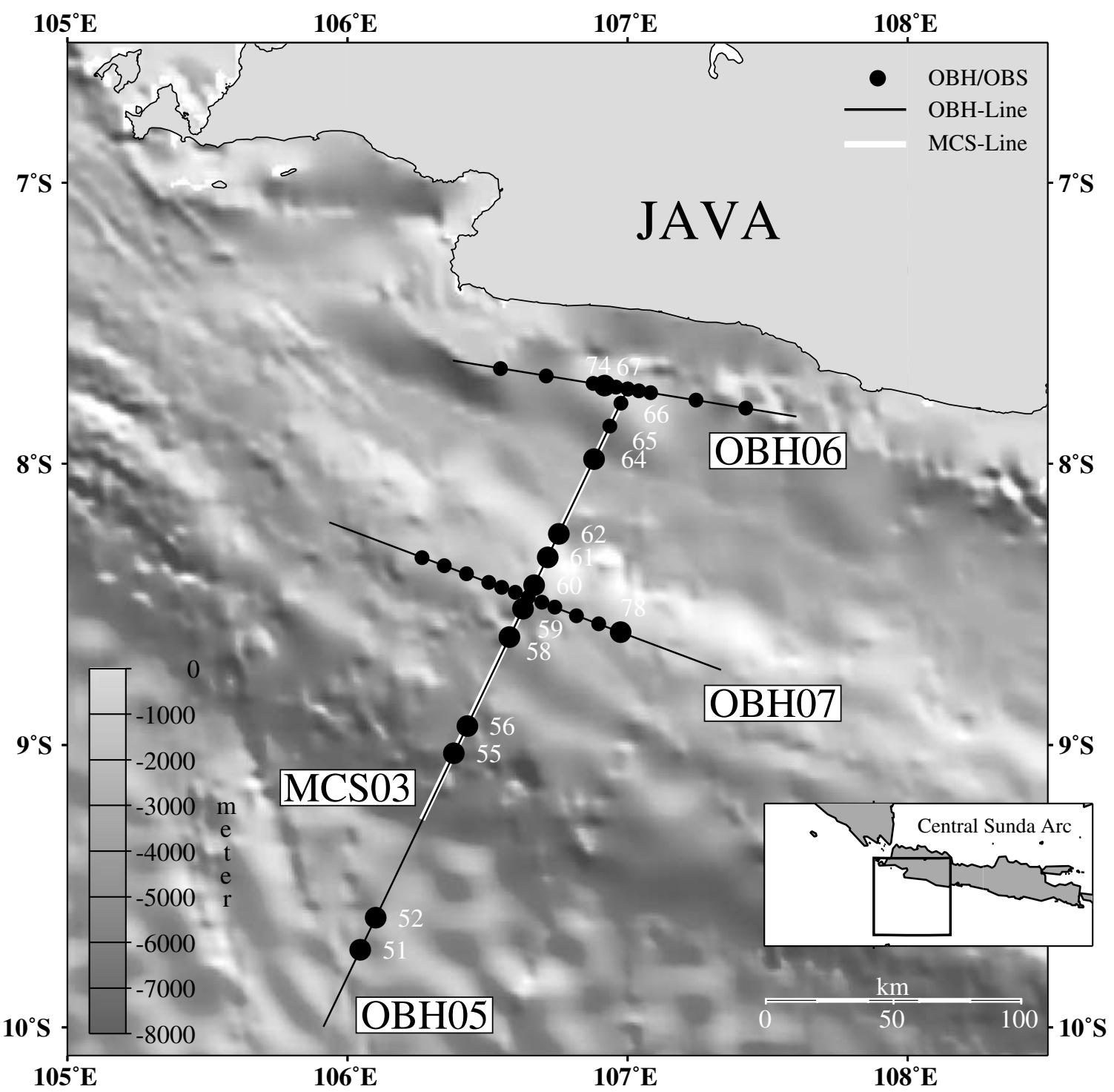

Figure 2. Location map of the seismic experiment across the subduction complex off western Java. The seafloor bathymetry is illuminated from the northeast. A total of 35 instruments recorded wide-angle data along profiles totaling a length of $590 \mathrm{~km}$. Refraction and reflection seismic data were acquired along the corresponding dip lines OBH 05 and MCS 03 . Shooting along OBH 05 was extended for $\sim 90 \mathrm{~km}$ beyond the end of the MCS line onto the ocean basin. Additional wide-angle data were recorded along the two strike lines that are located along strike of the crest of the outer high and the Javanese shelf, respectively.

al., 1994]. The motion of Australia with respect to West Java occurs at $67 \mathrm{~mm} / \mathrm{yr}$ in a direction $\mathrm{N} 11^{\circ} \mathrm{E}$, which is orthogonal to the trench. The West Java vector shows a velocity value of $30 \mathrm{~mm} /$ $\mathrm{yr}$ in a direction $\mathrm{N} 140^{\circ} \mathrm{E}$ with respect to the International Terrestrial Reference Frame 1992 (ITRF92) [Tregoning et al., 1994]. This has been interpreted as a manifestation of a West Java motion with respect to the distinct Sunda Block (Figure 1) in a northeast direction, as proposed by Wilson et al. [1998]. However, the relative motion of the Sunda Block with respect to Eurasia is $\sim 20 \mathrm{~mm} / \mathrm{yr}$ in a northeast direction [Wilson et al., 1998], which supports the interpretation of the West Java motion as a result of plate margin deformation.

[4] The age of the incoming plate increases from Sumatra in the west to Flores in the east. Off western Java the crustal age is estimated to be $96 \mathrm{Ma}$ [Diament et al., 1990]. The increase in age is consistent with an increase in plate dip along the arc [Widiyantoro and van der Hilst, 1996] and an increasing depth of seismic activity. West of Sunda Strait, seismicity is not generated beneath
$250 \mathrm{~km}$ depth [Puspito and Shimazaki, 1995], while beneath Java, earthquakes with focal depths of up to $670 \mathrm{~km}$ occur. Widiyantoro and van der Hilst [1996] suggest that the plate is continuous across a seismic gap between 350 and $500 \mathrm{~km}$ beneath this part of the arc.

[5] Sunda Strait (Figure 1) also seems to be a transition zone in the morphology of the forearc domain [Malod et al., 1995]. A distinct forearc basin, divided into several large subbasins, is present off Sumatra [Moore et al., 1980]. It vanishes off Sunda Strait and reappears off Java, where it displays a greater depth and is more continuous than its Sumatran analogue. The outer high, which represents the fossil accretionary domain, is larger in the Sumatran sector where sediment influx on the incoming plate is greater than off Java. Off Java the outer high is completely submerged and generally $2000-3000 \mathrm{~m}$ deep, with isolated highs reaching depths around $1000 \mathrm{~m}$ [Moore et al., 1980]. The variations in seismicity and forearc morphology are linked to the different tectonic settings resulting from the along-strike change of geophysical parameters discussed above, foremost the age of the 
subducted plate and the curvature of the trench. Moore et al. [1980] present single-channel reflection profiles south of Java and investigate the trench slope and slope basins. The data show all the morphological elements of a subduction zone (deep trench, slope basins with sedimentary fill, outer high, forearc basin); however, the internal structure is not resolved [Moore et al., 1980]. From an early seismic refraction line off central Java, Curray et al. [1977] interpret oceanic crust to be present beneath the forearc basin, but they fail to track the downgoing plate.

\section{Seismic Data}

\subsection{Data Acquisition}

[6] Seismic wide-angle measurements were conducted during leg SO138 of the German R/V Sonnein early 1999 along three profiles off western Java [Flueh and Shipboard Science Party, 1999]. Profile SO138-05 covers $\sim 80 \mathrm{~km}$ of oceanic crust seaward of the Java trench, the frontal active accretionary domain and fossil inactive accretionary outer high, and the forearc basin before terminating on the Javanese shelf (Figure 2). The profile is coincident with MCS line SO137-03 collected during leg SO137 [Reichert and Shipboard Science Party, 1999], though the wideangle shooting was extended seaward $90 \mathrm{~km}$ beyond the end of the MCS line to obtain reversed coverage on the oceanic crust. In addition, two cross lines were shot: Profile $\mathrm{OBH} 07$ runs along the crest of the outer high while profile OBH06 lies at the northeastern end of the dip line, close to the shelf break along the northwest boundary of the forearc basin (Figure 2).

[7] A total of 39 instruments were deployed on the various profiles, mainly the GEOMAR ocean bottom hydrophones (OBH) [Flueh and Bialas, 1996] and a few ocean bottom seismometers (OBS). Locations are shown in Figure 2. The seismic signals were generated by a tuned set of 20 air guns grouped in two identical linear subarrays. The total volume of the array is $51.2 \mathrm{~L}$ (3.124 cubic inches). The shots were triggered at a time interval of $60 \mathrm{~s}$ at a speed of 5.5 knots, resulting in an average shot point distance of $167 \mathrm{~m}$. Wide-angle data processing included relocation of the instrument position by analyzing the direct arrivals and application of a low-cut frequency filter. A two-gated predictive deconvolution was applied to the data to improve the temporal resolution. Owing to the broad frequency range contained in the data and to the highly variable seafloor depth along the profiles, a time-dependent and offset-dependent frequency filter was applied. The seismic energy was sufficient to trace signals on the record sections to distances between 60 and $80 \mathrm{~km}$, and data quality is good on average. Only selected examples of record sections are shown in the following.

[8] For the MCS data acquisition the same source as for the OBH data acquisition was used, and signals were received along a $3.5-\mathrm{km}$-long streamer with 120 channels and a recording length of $14 \mathrm{~s}$. The shot interval was $50 \mathrm{~m}$, and the hydrophone spacing was $25 \mathrm{~m}$, resulting in a common midpoint (CMP) distance of $12.5 \mathrm{~m}$ and a fold of 30 . After trace editing and balancing, a frequency filter was applied. Special attention was devoted to the frequency-wave number (f-k) domain multiple removal process, which is based on move out differences between primary and multiple events in the CMP gather. A trace interpolation was applied to prevent aliasing before $\mathrm{f}-\mathrm{k}$ multiple reduction. A two-gated predictive deconvolution further suppressed the multiple and enhanced signal resolution. Because of the significant relief of the seafloor, coherency within the CMP gathers is limited. Thus the demultiple process is inhibited so that multiple energy still remains, especially beneath the outer high. A poststack time migration was achieved to complete the processing sequence. It was interactively improved using a smoothed velocity field as derived from modeling the wide-angle data.
[9] Figure 3a displays the southern part of the MCS line, covering the trench and deformation front, which lie at a water depth of over $6300 \mathrm{~m}$. The top of the subducted plate is visible for a distance of $>80 \mathrm{~km}$ landward of the deformation front. The frontal part of the subduction complex is characterized by a rugged topography, which becomes smoother landward of a backstop structure (common depth point (CDP) 14000). A thin sedimentary cover is visible here above a rough top basement. Figure $3 \mathrm{~b}$ shows the landward part of the profile from the crest of the outer high to the Java shelf. Thicker sequences of ponded sediment have been trapped in several basins above the top basement. Reflectivity is low within the outer high beneath the top basement. This part of the profile is partly obscured by remnants of the seafloor multiple. Farther landward, the well-resolved sediment fill of the forearc basin onlaps onto the Java shelf and shows some deformation along the seaward part of the basin.

\subsection{Modeling}

[10] To reveal the deep structure of the margin, both wide-angle and reflection seismic data were incorporated in an integrated interpretation of both data sets. Because of the different demands concerning the shot interval for wide-angle and multichannel recordings, the $\mathrm{OBH}$ and MCS data acquisition were realized independently; however, as they are shot along coincident tracks, a joint analysis is feasible. In areas of complex topography this requires accurate navigation. An alignment of the seafloor reflection and the water depth (Figure 4) shows good compatibility between the two data sets except for a short part of the line from profile $\mathrm{km} 100$ to 120 , where apparently the profiles do not fully overlap.

[11] A forward modeling technique [Luetgert, 1992] was chosen for the wide-angle data, and the resulting crustal model for all three OBH profiles is shown in Figure 5. The forward modeling is based on kinematic ray-tracing algorithms [Červený et al., 1977; BenMenahem and Beydoun, 1985; Beydoun and Ben-Menahem, 1985] in which theoretical rays and their corresponding travel times are calculated from a 2-D laterally heterogeneous model and subsequently compared to the acquired wide-angle data. This comparison will be displayed in Figures 7-17 for a number of $\mathrm{OBH}$ stations. For this iterative approach a velocity-depth model, like the one displayed in Figure 5, is constructed until the calculated travel times adequately fit the observed data (e.g., Figure 8 ). The quality of the achieved velocity model mostly depends on the qualitative estimate of phase identification uncertainty. First arrivals of the $\mathrm{OBH}$ data in the near-offset range $(<30 \mathrm{~km})$, including refracted waves in the sedimentary section of the outer high and refracted waves through the oceanic crust, could be accurately identified with uncertainties less than $\pm 50 \mathrm{~ms}$. At larger offsets, accuracy declined to about $\pm 100 \mathrm{~ms}$ due to a lower signal-to-noise ratio. Events from the plate boundary are clear and continuous for 30-40 $\mathrm{km}$ on several stations beneath the outer high of the dip line, with decreasing amplitudes and clarity farther landward at greater depth. Their travel times could also be picked with errors varying from \pm 50 to $\pm 100 \mathrm{~ms}$. PmP reflections from the oceanic Moho were clearly recorded by stations deployed on the outer high, though the picking accuracy only lies between \pm 100 and \pm 150 ms due to their late arrivals which partially interfere with earlier events and noise. Wide-angle data from profile SO138-05 (Figure 5) have a very complex travel time pattern due to the rapid change in water depth and the variable composition of the frontal accretionary prism and outer high. As the energy penetration along the dip line is greatest, we started by modeling this profile first. The velocity tie points were later used to determine the velocity field along the two strike lines. The velocity model along profile 05 was developed from modeling identified arrivals in the $\mathrm{OBH}$ data, incorporating prominent events in the reflection data applying a top-to-bottom approach. The near-vertical incidence reflections in the MCS data (Figures $3 \mathrm{a}$ and $3 \mathrm{~b}$ ) helped to position the top basement beneath the 
$1-5$
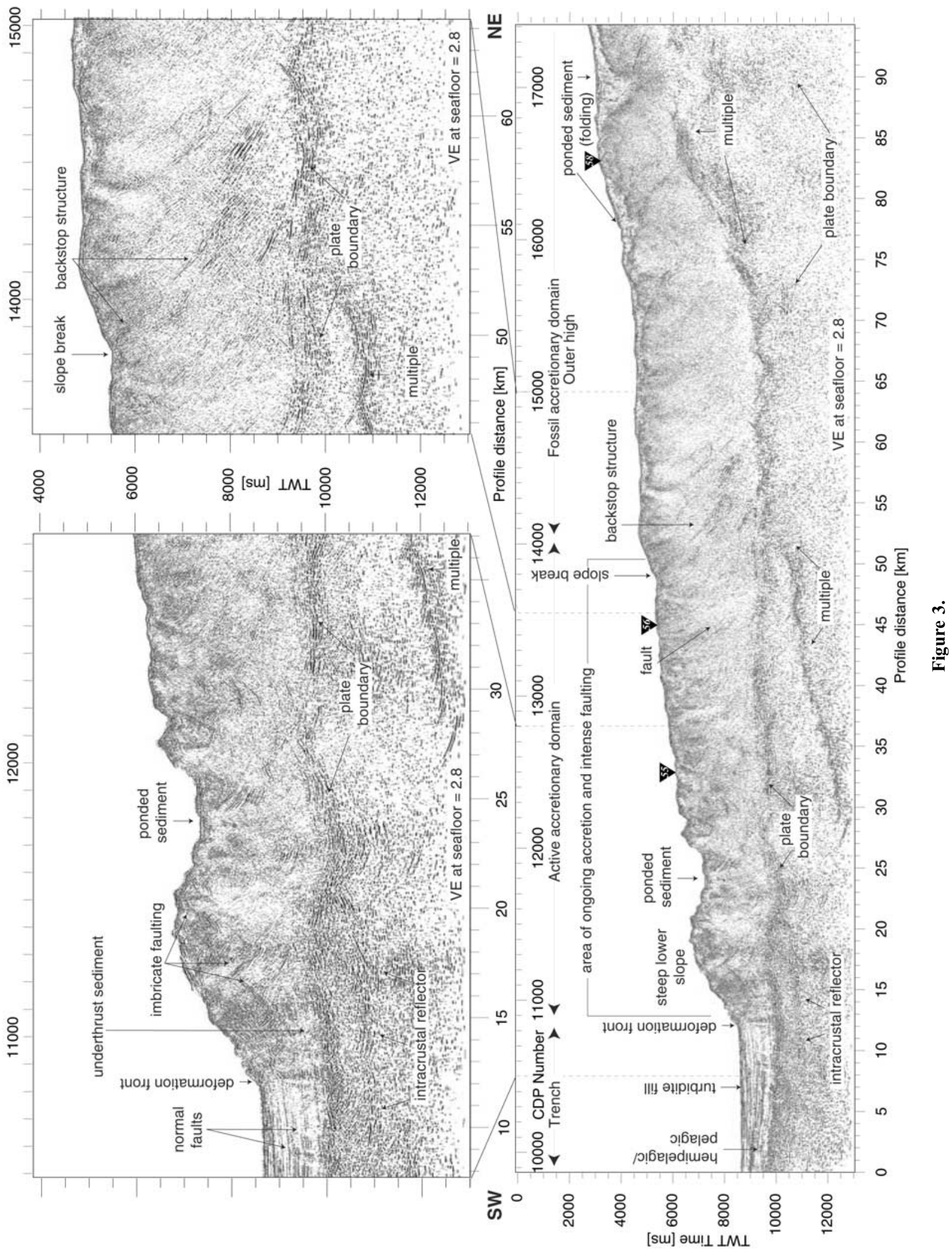


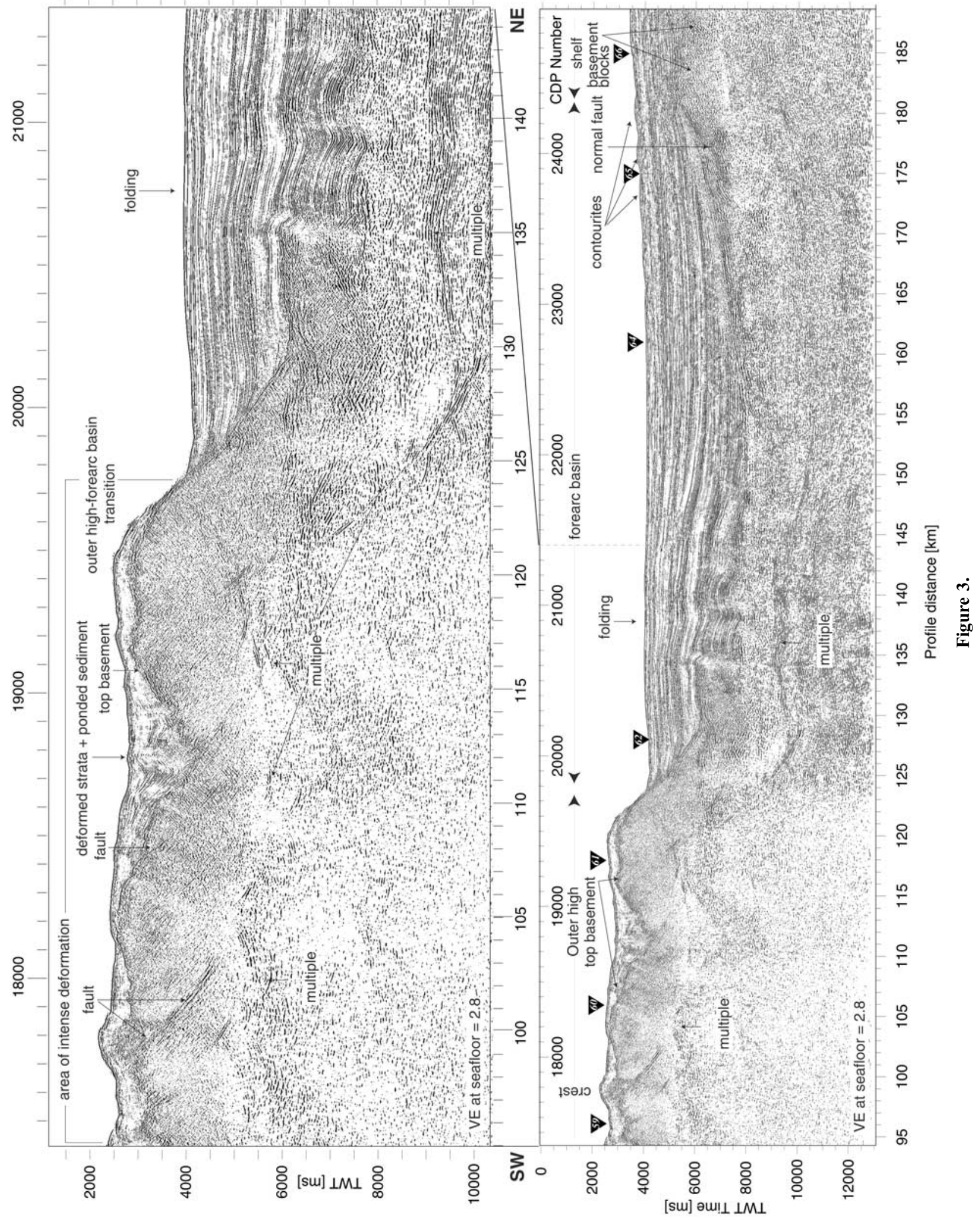




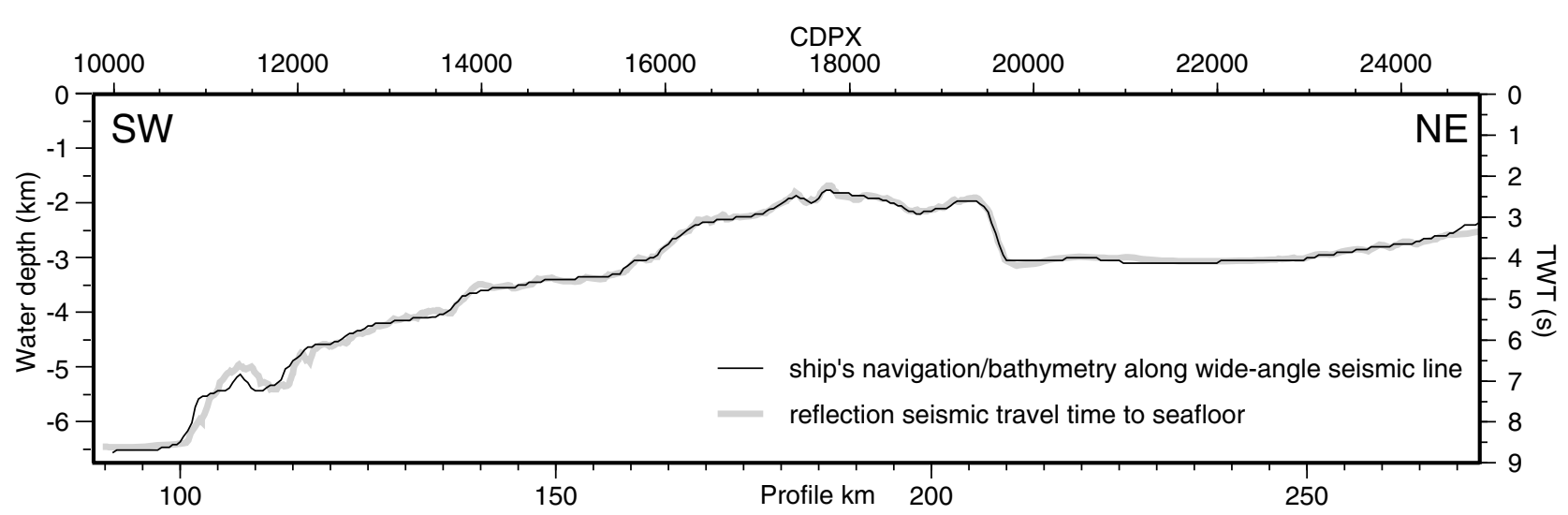

Figure 4. Comparison of the seafloor bathymetry along profile OBH 05 to the two-way travel time to the seafloor of corresponding line MCS 03 to ensure compatibility of the two data sets. The profiles were not acquired simultaneously to meet the different demands concerning the shot interval for wide-angle and reflection data. Equal geometries during data acquisition should yield an identical fit of the bathymetry and travel time to the seafloor for the two lines. This criterion must be fulfilled in order to correlate the two profiles. Good compatibility was achieved along the lines except for a distance of $\sim 20 \mathrm{~km}$ landward of the deformation front.

outer high (Figure 3b, CDPs 16000-19700) and the top of the subducted plate near the trench (CDPs 10000-17100) as well as the basement beneath the forearc basin and the shelf onset (CDPs 20000-24900, see Figures 3a and 3b).

[12] Modeling of the strike lines yielded basic velocity information of the outer high and the Java shelf, which was tied to the velocity structure of the dip line (Figure 5). Thus further constraint on the velocity structure was achieved. Reflection data recorded by a three channel ministreamer along strike lines 06 and 07 [Flueh and Shipboard Science Party, 1999] helped to model the upper segments of the strike lines.

[13] Figure 6 displays the final wide-angle velocity model of the dip line converted to a time section and overlain by a line drawing of the MCS data. Good correlation of the main reflection horizons with significant velocity changes in the subsurface was achieved.

\section{Interpretation}

\subsection{OBH Profile SO138-05 and Coincident MCS} Profile SO137-03

4.1.1. Ocean basin and trench. [14] OBH line SO138-05 is $280 \mathrm{~km}$ long and extends from the Java shelf beyond the end of the MCS profile to the ocean basin (Figure 5). Two instruments (OBH 51 and $\mathrm{OBH} 52$, Figure 7) recorded data on the oceanic crust seaward of the trench, which allow some insight into the structure of the igneous crust. The incoming plate is covered by $600 \mathrm{~m}$ of pelagic and hemipelagic sediment, and a normal oceanic crust of $7.4 \mathrm{~km}$ thickness is observed. The upper oceanic crust of $2 \mathrm{~km}$ thickness was modeled with a higher velocity gradient than the lower crust (layer 3), which displays a velocity increase from 6.5 to
$7.2 \mathrm{~km} / \mathrm{s}$. Phases Puoc and Poc (Figure 7) are refracted through the upper and lower crust, respectively. The trench sediment fill is inferred from the MCS data (Figure 3a, CDPs 9900-10800), in which hemipelagic/pelagic sediment and turbidite fill is resolved. From the southwestern end of MCS profile SO137-03 up to about CDP 10800 the trench fill is characterized by near parallel, subhorizontal, and landward divergent reflectors that onlap the basement. Two landward normal faults cutting the pelagic sediment around CDP 10600 and CDP 10700 (Figure 3a blowup) seem to be inactive as they do not disturb the turbidite fill. Because of the great depth of the trench of $>6.3 \mathrm{~km}$, no instruments could be deployed here. Unfortunately, one instrument deployed immediately landward of the trench failed to record any data.

4.1.2. Subducted plate. [15] The next two stations (OBH 55 and OBH 56, see Figure 3a) trace the top of the subducted plate as a strong reflection Ptoc (toc denotes top of oceanic crust) and refraction Poc (oc denotes oceanic crust) (OBH 55 and OBH 56 in Figures 8 and 9). The plate boundary is also present in the multichannel data, where it occurs as a high-amplitude reflection. This reflection displays strong lateral coherency (Figure 3a). An intracrustal reflection is recorded $\sim 0.8 \mathrm{~s}$ two-way time (TWT) later (Figure 3a). This phase Pioc is also clearly visible in the $\mathrm{OBH}$ data (OBH 55 and $\mathrm{OBH}$ 56) and is interpreted as the transition from upper to lower crust (ioc denotes intra-oceanic crustal reflector). Although phase Pioc is recorded by stations OBH 55 and OBH 56, its presence on the record section of OBH 58 is ambiguous since the arrivals from the subducted plate appear as a strong band of energy which does not clearly resolve the intra-oceanic crustal reflection. Where the intracrustal reflection marks the upper-lower

Figure 3. (a) Southwestern part of MCS profile SO137-03 from the trench to the outer high. The active accretionary domain extends from the trench to the present backstop structure (common depth point (CDP) 14100). The slope break above the backstop structure marks the transition from the active accretionary domain to the outer high which represent the fossil part of the accretionary prism. Whereas the active accretionary domain is disturbed by numerous active faults, the seaward part of the outer high shows little tectonic activity. The velocity model presented in Figure 5 shows laterally increasing velocities in the frontal active accretionary domain and laterally constant velocities beneath the fossil accretionary domain of the outer high. TWT, two-way time; VE, vertical exaggeration. (b) Northeastern part of the MCS profile SO137-03 covering the landward part of the outer high and the forearc basin and shelf onset. Toward the forearc basin, the outer high is undergoing compression as expressed in intense folding and faulting. The outer high-forearc basin transition is marked by a sharp boundary. Intense folding of the forearc basin sediments is still active; deformation ceases toward the shelf. The wavy seafloor topography between CDPs 23000 and 24500 is characteristic of contourites. The shelf is composed of several large basement blocks bounded by large normal faults. 


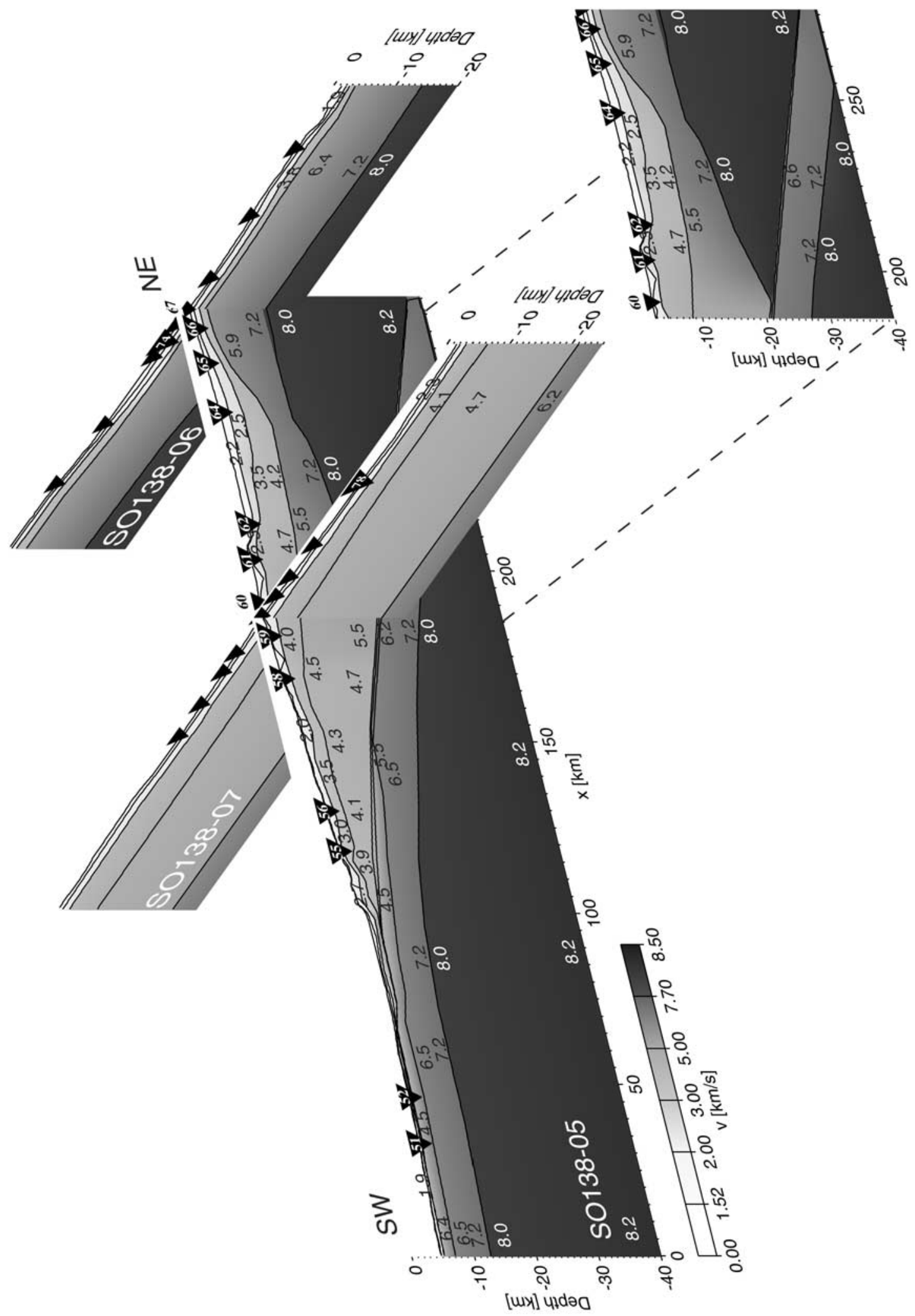

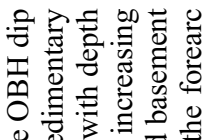

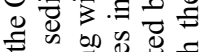
of $\approx$. 유유. 뭉.

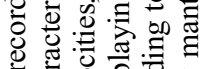
현영혀 जै.

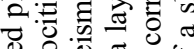

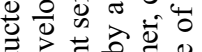

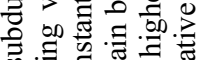

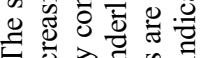

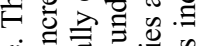

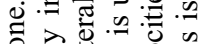

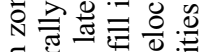

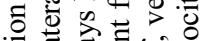

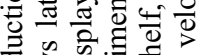

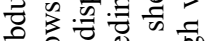

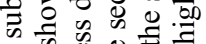

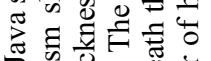
Ð

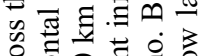

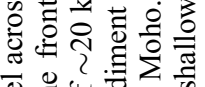
च 숭ㅎㅇ 을

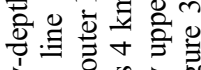

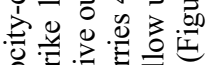

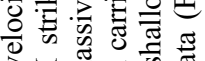

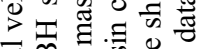
चี 要

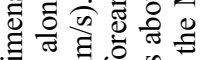

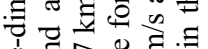

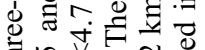

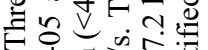

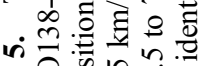

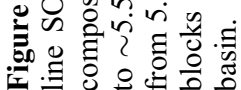




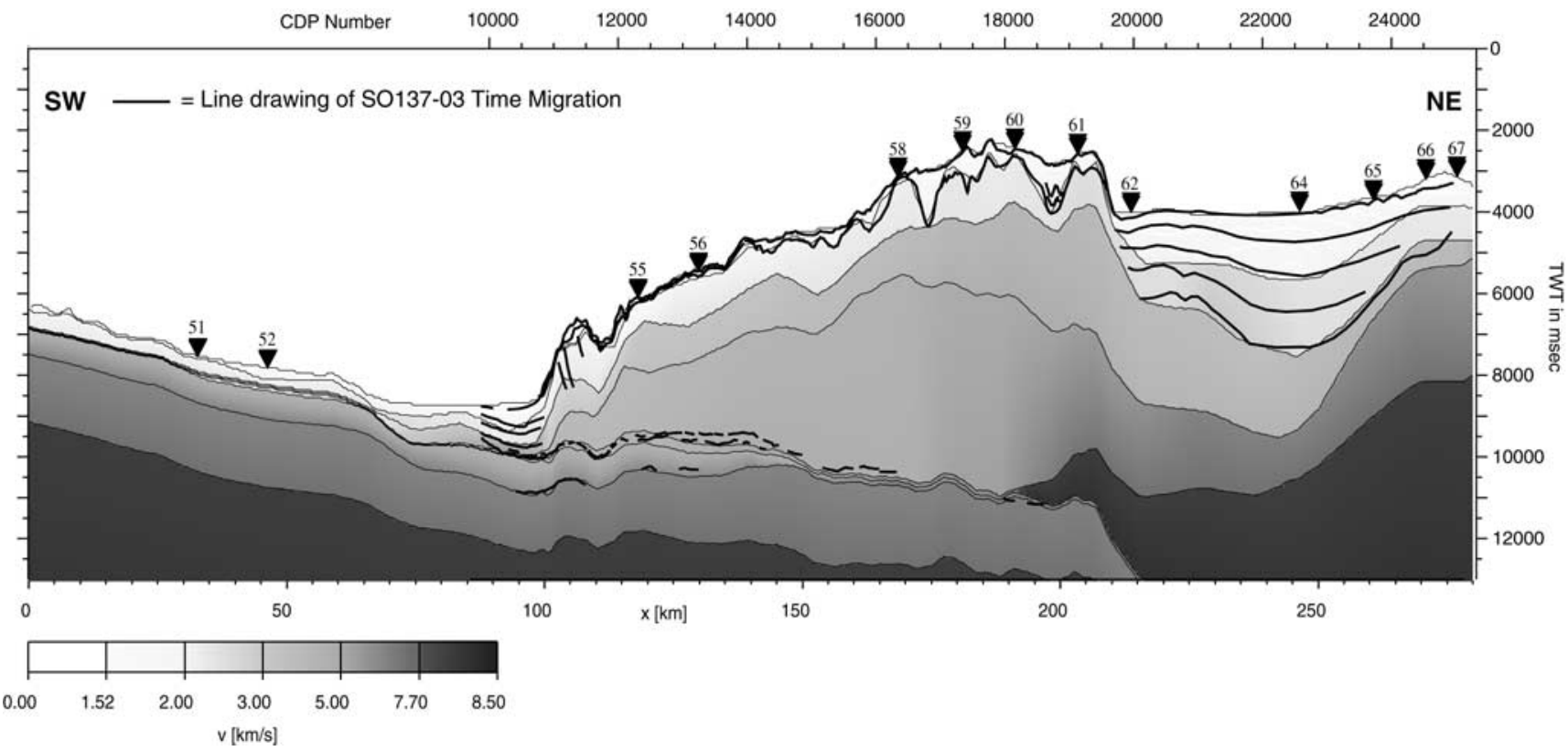

Figure 6. Line drawing of MCS 03 plotted on top of the wide-angle velocity model which was converted to a time section in two-way travel time. A good correlation of the main units in the upper segments of the wide-angle model to the near-vertical incidence reflections of the MCS data was achieved. The MCS recording started in the trench, where several layers of trench infill are resolved above the downgoing plate. The top of the subducted plate is visible for $\sim 80 \mathrm{~km}$ beneath the active accretionary domain and its corresponding fossil part, the outer high. An intracrustal reflector was recorded in the MCS as well as the OBH data $\sim 0.8 \mathrm{~s}$ below the top of the subducted plate beneath the frontal prism. The outer high displays the top basement beneath the upper sediment cover, which correlates with a significant velocity change in the wide-angle model. A maximum of $2.8 \mathrm{~s}$ of sediment fill is recorded in the forearc basin, onlapping onto the Javanese shelf.

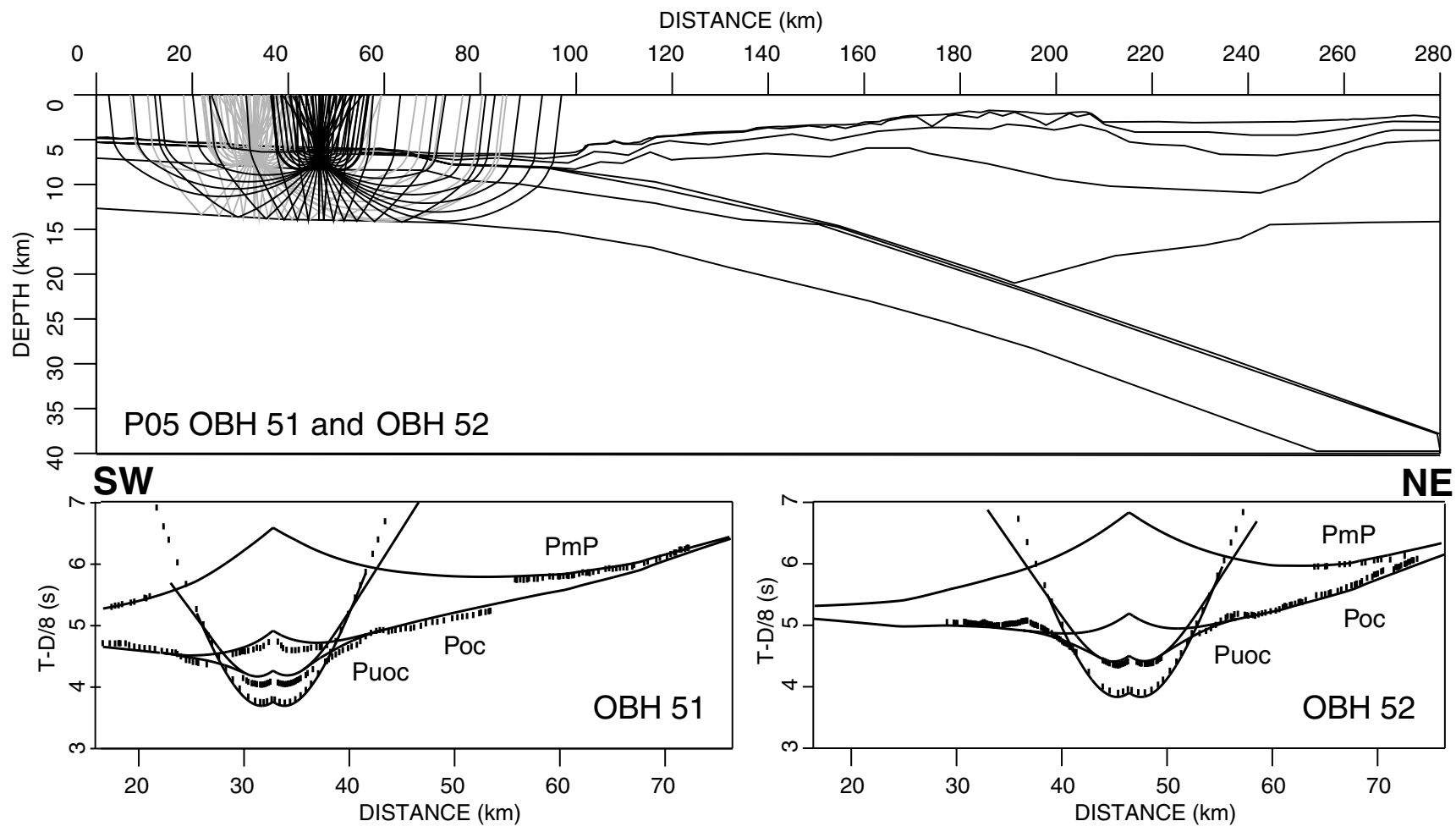

Figure 7. OBHs 51 and 52 are located on the incoming igneous oceanic crust which shows a thickness of $7.4 \mathrm{~km}$ and a normal velocity structure. (top) Ray paths through the model subsurface for both stations. (bottom) Travel time picks as stippled lines overlain by the calculated modeled travel times. Puoc indicates refracted waves through the upper oceanic crust (uoc) and Poc through the lower crust; PmP is the Moho reflection. 

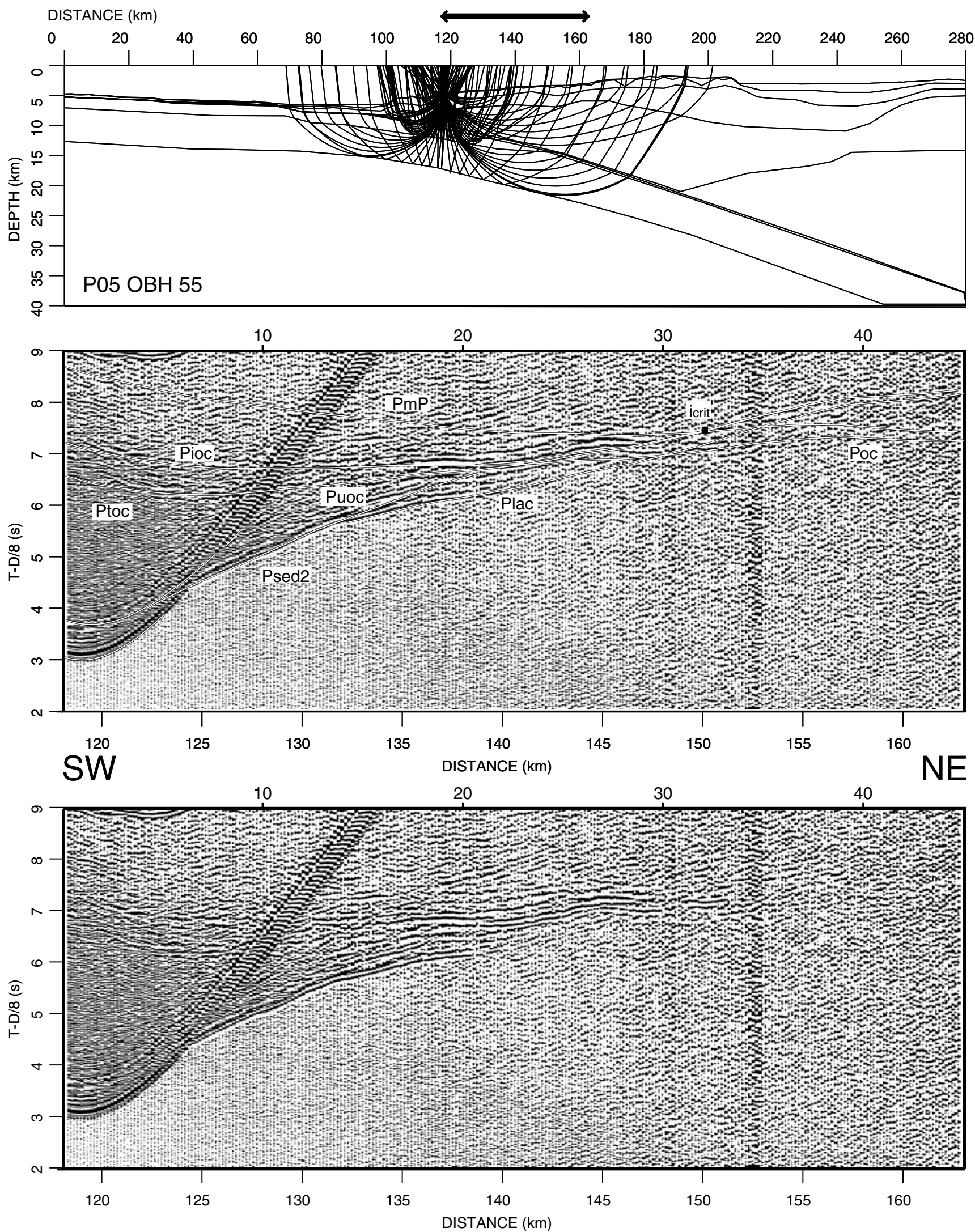

Figure 8. OBH 55, the first station landward of the trench. (top) Ray paths through the model subsurface. (middle) Data with overlain calculated travel times. (bottom) Raw data set for comparison. The top of the subducted plate Ptoc and an intracrustal reflector Pioc are recorded as reflections by stations 55 and 56 (Figure 9). The velocity structure of the accretionary domain is documented by the sedimentary phases Psed 2 and Plac (lower accretionary complex). The thick black arrow above the model distance axis signifies the transect displayed in the record section below. 

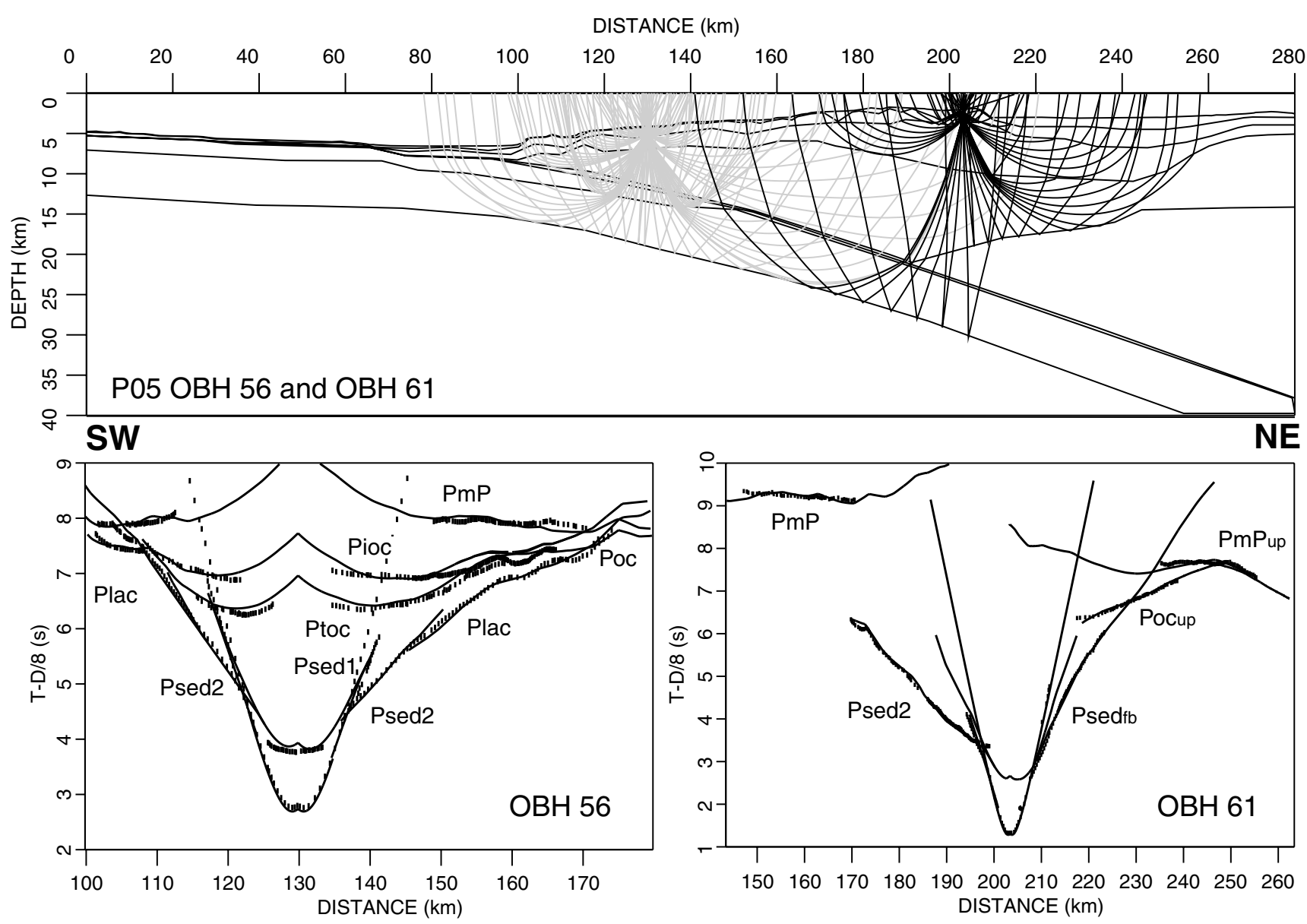

Figure 9. (top) Ray paths and (bottom) travel time picks of stations 56 and 61. For further display information, please refer to Figure 7. Both recorded the oceanic crust-mantle boundary. OBH 61 is the most landward station located on the outer high and recorded the forearc basin sediment fill $\left(\operatorname{Psed}_{\mathrm{fb}}\right)$ as well as the oceanic-type crust beneath the forearc basin ( $\left.\mathrm{Poc}_{\mathrm{up}}\right)$. The upper plate Moho beneath the forearc basin is traced by wide-angle reflection $P m P_{\text {up. }}$

oceanic crust transition on both data sets along the profile, we applied a distinct layering for the oceanic crust. Phases indexed uoc (uoc denotes upper oceanic crust) indicate refracted waves through the upper crust (OBH 51, OBH 52, and OBH 55). Starting around profile $\mathrm{km} \mathrm{140,} \mathrm{this} \mathrm{transition} \mathrm{is} \mathrm{no} \mathrm{longer} \mathrm{resolved,} \mathrm{and} \mathrm{thus} \mathrm{we}$ applied a single velocity gradient with depth for the subducted plate. OBH 58 and OBH 59 record the top of the plate at $\sim 17 \mathrm{~km}$ depth at profile km 170 (Ptoc and Poc in Figures 10 and 11).The plate boundary is also present on the record section of station 60 (Figure 12). OBH 62 (Figure 13) is the most landward instrument to record it at a depth of $26 \mathrm{~km}$ at profile $\mathrm{km} \mathrm{215}$. A strong Moho reflection from the oceanic plate was recorded by OBH station 62 (Figure 13), which is located immediately landward of the outer high in the forearc basin. PmP is identified from high amplitudes at offsets beyond the critical angle $i_{\text {crit }}$ (Figure 13). This arrival enables us to identify the oceanic Moho to a depth of $25 \mathrm{~km}$ at $\mathrm{OBH}$ profile $\mathrm{km} 170$.

4.1.3. Frontal prism: The active accretionary domain. [16] Good coverage of the toe of the frontal prism, which represents the active accretionary domain, was achieved at stations 55 and 56 (Figures 8 and 9). The deformation front is located at $\mathrm{OBH}$ profile $\mathrm{km} 100$ and is characterized by a steep onset of $\sim 13^{\circ}$ of the lower slope. Several smaller ridges and a number of thrust faults, some of which cut through almost to the top of the subducted plate, are visible (Figure 3a blowup). Small volumes of ponded sediment have been trapped between the ridges, but no pelagic sediment cover is visible atop the recent accretionary unit in the MCS data. The velocity structure of the frontal active accretionary domain was determined from refracted waves through the upper sedimentary units (Psed1 and Psed2) and through the lower accretionary complex (Plac; lac denotes lower accretionary complex) mainly from the six OBH stations $(55,56$, and 58-61) positioned on the accretionary wedge and outer high. The smooth velocity-depth functions are characterized by a positive downward and landward gradient. The upper units show low velocities $(2.7-3.0 \mathrm{~km} / \mathrm{s})$ (Figure 5), while the lower part of the frontal prism displays seismic velocities from 3.9 to $4.1 \mathrm{~km} / \mathrm{s}$, which show little lateral variation for the first $20 \mathrm{~km}$ of the frontal prism. This is documented by phases Psed2 and Plac of OBH 56 between $\mathrm{OBH}$ profile $\mathrm{km} 100$ and 120 (Figure 9). Velocities increase laterally by $\sim 0.5 \mathrm{~km} / \mathrm{s}$ from 20 to $35 \mathrm{~km}$ landward of the deformation front, as shown by the landward traveling phases Psed2 and Plac of station 55 (Figure 8), before leveling at an

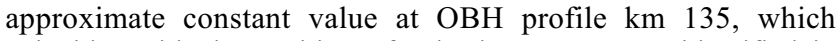
coincides with the position of a backstop structure identified in the MCS data (Figure 3a). The velocity structure of the frontal part of the wedge, which composes the active accretionary domain, is also supported by the southwest running phases Psed 2 and Plac of OBH 58 and OHB 60 (Figures 10 and 12).

4.1.4. Outer high: The fossil accretionary domain and the adjacent forearc basin. [17] The backstop structure is identified in the MCS data as a prominent, landward dipping reflection. It cuts from the seafloor at the trench slope break to the top of the subducted oceanic plate (Figure 3a blowup). The backstop 

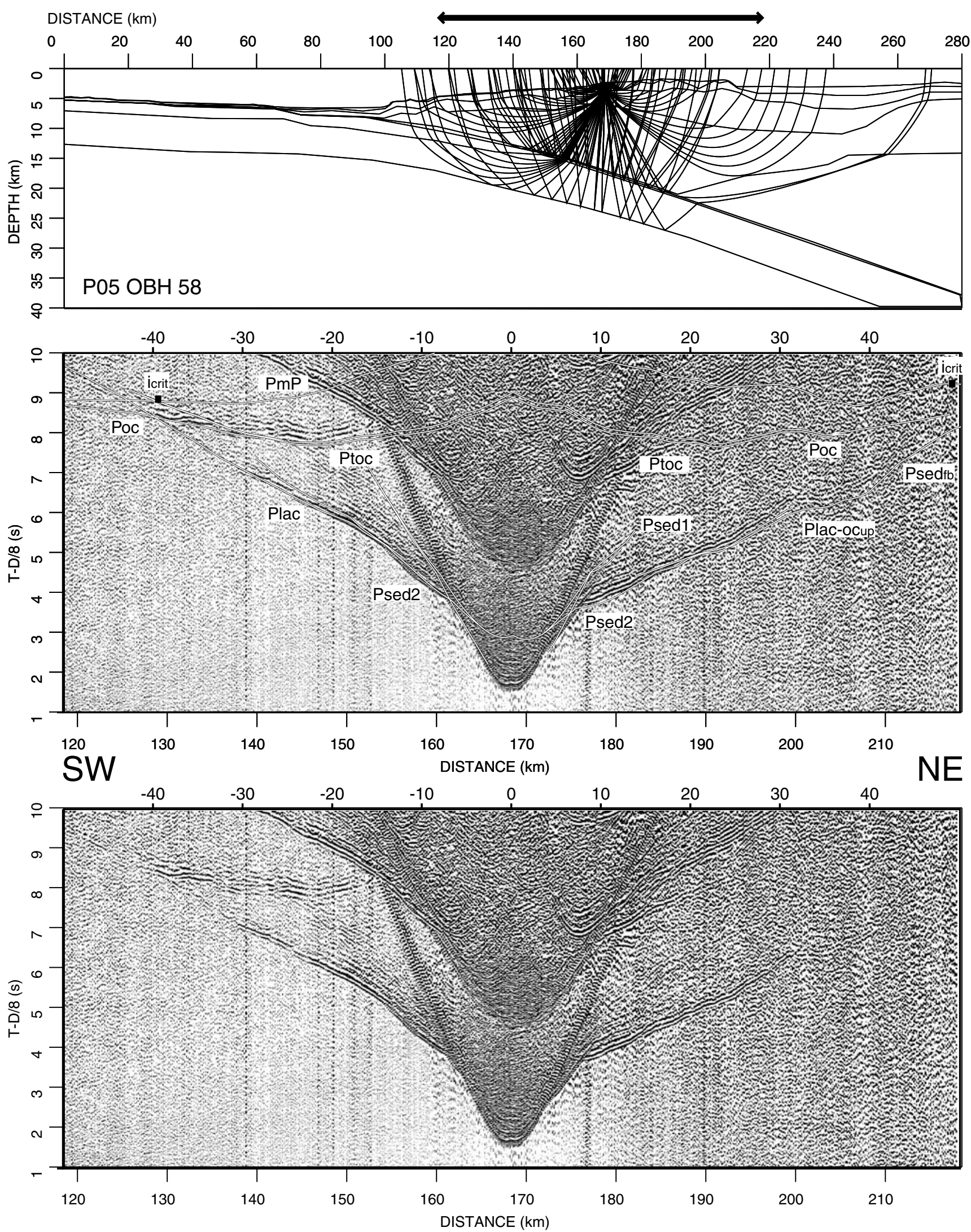

Figure 10. Ray paths and seismic section for OBH 58. For further display information, please refer to Figure 8. Strong phases Ptoc and Poc track the downgoing slab. The seaward sedimentary phases Psed 2 and Plac document the velocity structure in the accretionary domain. Landward, phase Plac-oc $\mathrm{up}_{\mathrm{up}}$ travels through the lower accretionary complex as well as through the oceanic-type crust beneath the forearc basin before passing through the forearc basin sediments $\left(\right.$ Psed $\left._{\mathrm{fb}}\right)$. 

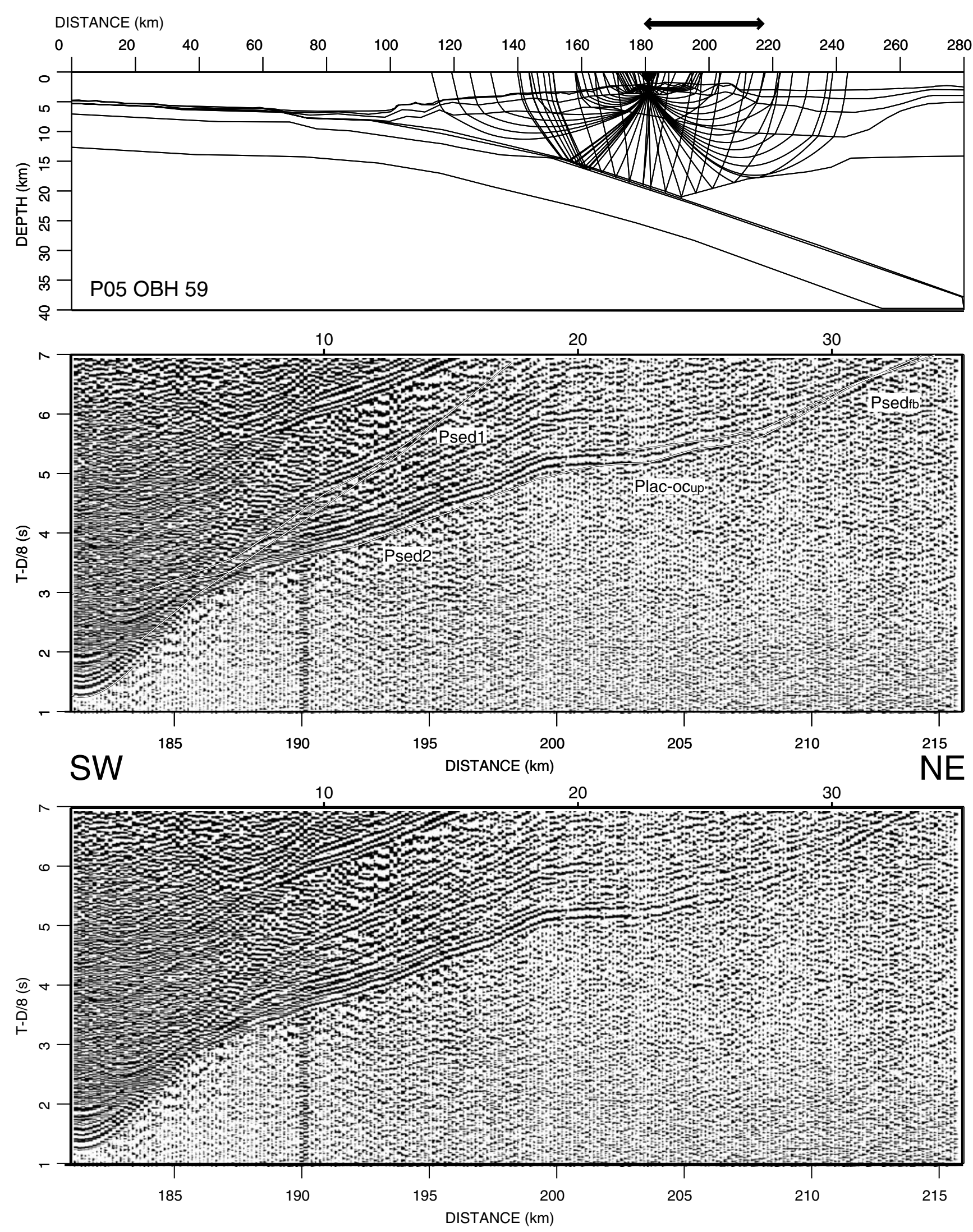

Figure 11. Same as Figure 10 for OBH 59, located near the crest of the outer high. For further display information, see Figure 8. Phases Psed2 and Psed $_{\mathrm{fb}}$ cover the sedimentary sequences of the outer high and forearc basin. Arrivals of Plac-oc ${ }_{u p}\left(\right.$ lac-oc $_{\mathrm{up}}$ denotes lower accretionary complex-oceanic-type crust of upper plate) traveled through the layer of high velocities underlying the forearc basin sediments as is documented by the high velocities at $20-25 \mathrm{~km}$ offset. At larger offsets, velocities decrease again as they travel through the sediment fill of the forearc basin $\left(\operatorname{Psed}_{\mathrm{fb}}\right)$. 

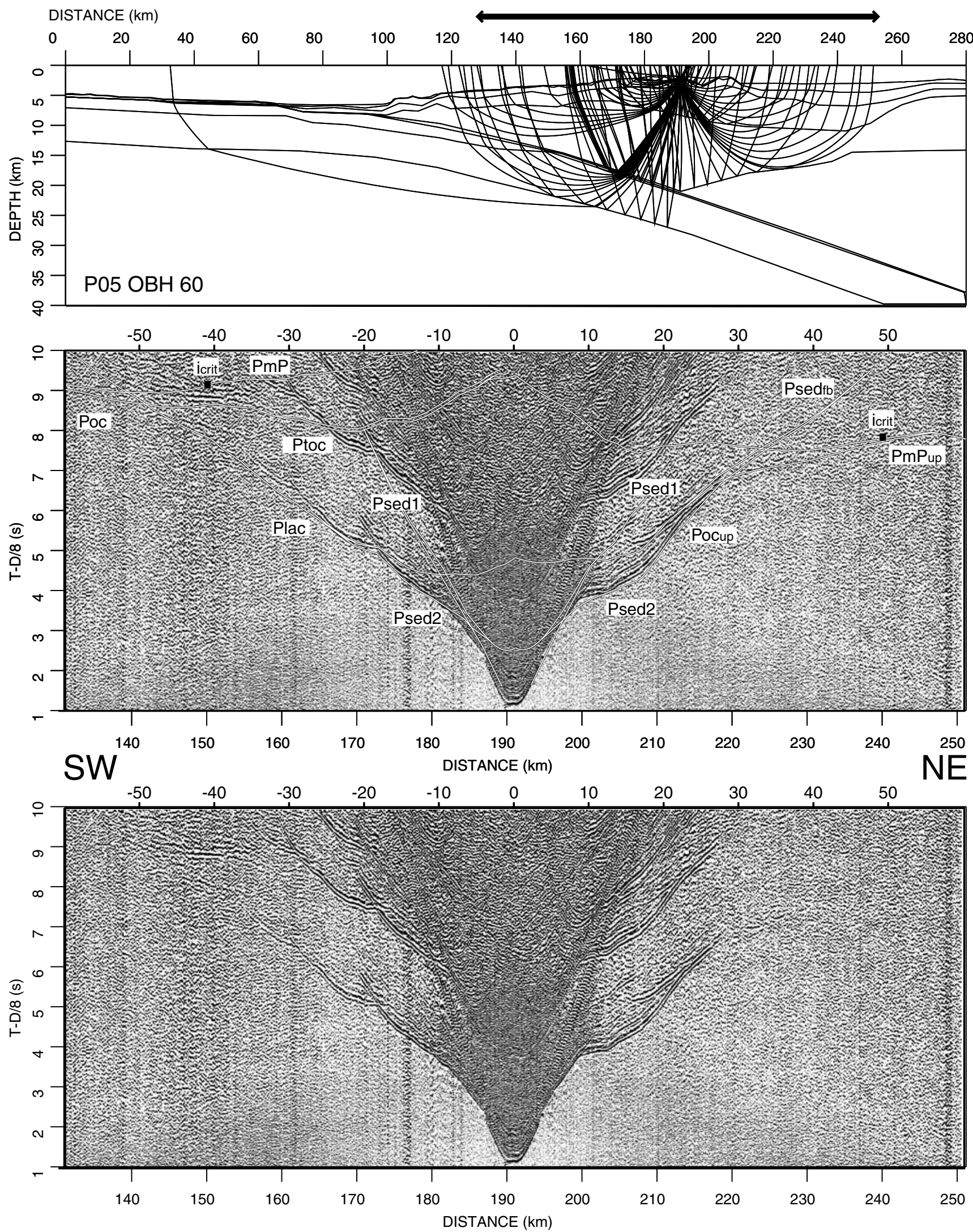

Figure 12. Ray paths and seismic sections for OBH 60 which covers part of the frontal active accretionary domain, the outer high, and parts of the forearc basin. For further display information, please refer to Figure 8 . Phases Ptoc and Poc track the subducted slab beneath the outer high. The velocity structure of the accretionary domain is validated by the seaward phases Psed2 and Plac. The landward sedimentary phases verify the velocity increase beneath the forearc sediments at an offset range from 9 to $16 \mathrm{~km}$. The upper plate crust-mantle boundary beneath the forearc basin is recorded as wide-angle reflection $P m P_{\text {up }}$. 

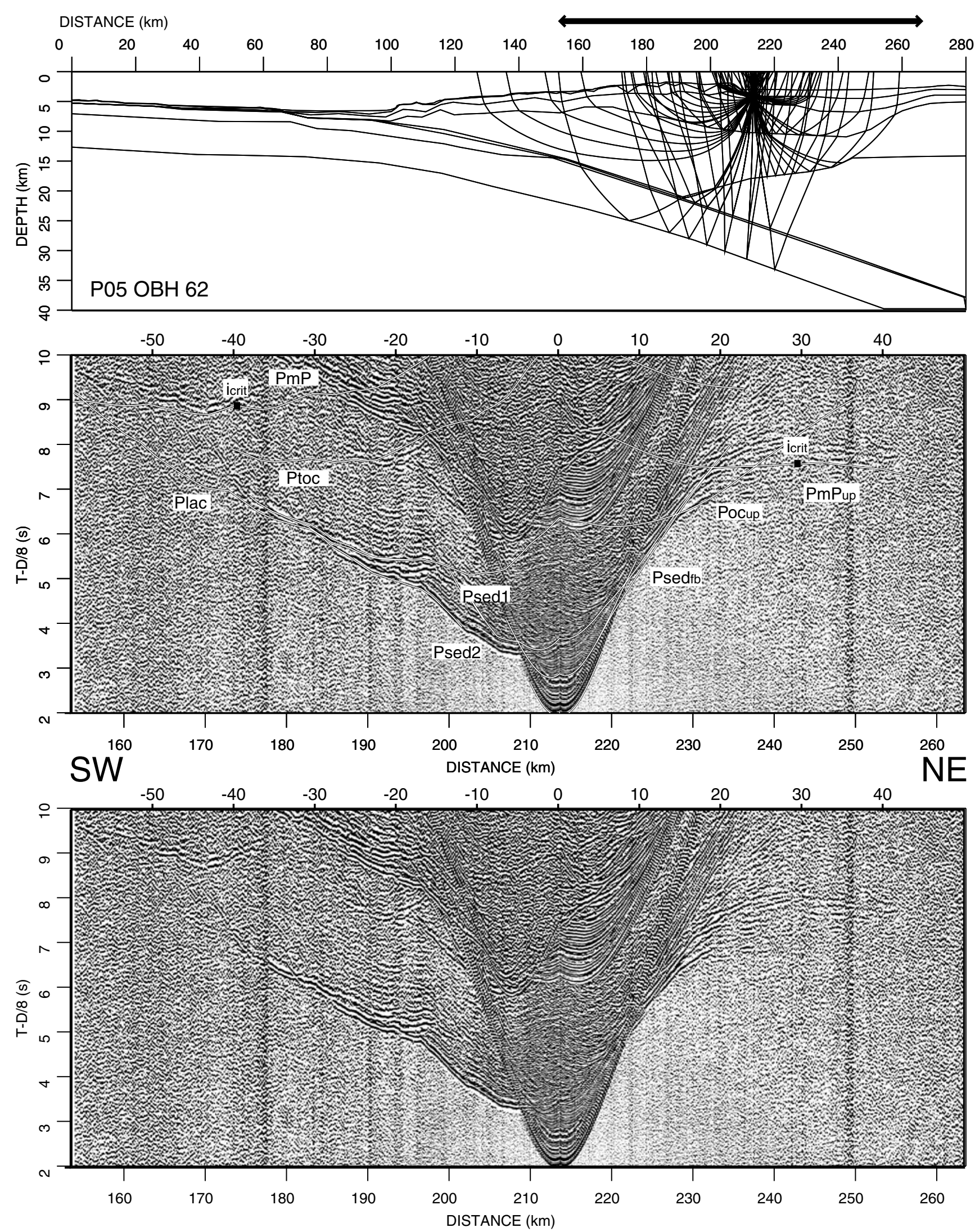

Figure 13. OBH 62, the most landward station recording the top of the subducted plate Ptoc and the oceanic Moho $P m P$ of the downgoing slab. For further display information, see Figure 8. The upper plate crust-mantle boundary beneath the forearc basin is validated by wide-angle reflection $P m P_{\text {up }}$, which becomes visible at offsets beyond the critical angle $i_{\text {crit }}$. The mantle velocity beneath the forearc basin is calculated from this critical angle and lies between 7.9 and $8.1 \mathrm{~km} / \mathrm{s}$. 


\section{ETG 1 - 16 KOPP ET AL.: CRUSTAL STRUCTURE OF THE JAVA MARGIN}

structure marks the transition from the active accretionary domain at the front of the subduction complex to the more elevated topography of the outer high, which we regard as the fossil, inactive part of the accretionary domain. The backstop structure must thus be viewed as marking the present, most recent backstop. Landward of the slope break the seafloor topography is smoother than in the active accretionary domain, and some sediment cover becomes apparent in the MCS data (Figures 3a and 3b). Beneath this sediment cover a clear top basement is visible, forming ridges and troughs in which ponded sediment is trapped. Landward of the slope break (roughly between CDP 14000 and CDP 15500), little evidence for tectonic activity can be recognized. Toward the forearc basin (between CDP 16000 and CDP 19800), compressional forces are active and strata deformation and tectonic activity increase. Recent tectonic movement is documented by folded sedimentary strata and active faults which crop out at the seafloor (CDPs 17700-18000). Folding appears to be active, as the seafloor sediment is affected (CDP 18800). The transition from the outer high to the forearc basin is characterized by a steep flank (CDPs $19500-$ Figure $3 \mathrm{~b}$ ), dipping $\sim 25^{\circ}$. This transition is extremely sharp, and recent deformation is evident in folded forearc sediment $10 \mathrm{~km}$ landward of the outer high (CDPs 2000021800 , Figure $3 \mathrm{~b}$ ). The thick sedimentary sequence of the forearc basin is well documented by the reflection data. Deformation becomes less intense toward the shelf. The top basement lies at $7.5 \mathrm{~s}$ TWT in the center of the basin and is covered by younger sediment. The younger sequences onlap onto these strata. The seismic character of the top basement changes toward the shelf, where high, low-frequency amplitudes prevail. In contrast, in the center of the basin, reduced amplitudes trace the gentle relief of the top basement here. The wavy seafloor topography between CDP 23000 and CDP 24500 (Figure 3b) is a possible indication for contourites. Moore et al. [1980] report on canyons cutting the Javanese shelf and extending into the deeper parts of the basin. These canyons would play an important role in terrigenous sediment transport and deposition. Evidence for normal faulting is also found in the Javanese shelf, where large seaward dipping faults occur at CDP 24000 and CDP 22200.

[18] Velocities of the outer high behind the actively accreting wedge (i.e., within the first $60 \mathrm{~km}$ from the deformation front) range from 2.2 to $\sim 4 \mathrm{~km} / \mathrm{s}$ for the upper segments (Psed2) and from 4.4 to $4.6 \mathrm{~km} / \mathrm{s}$ (Plac) between a depth of $6 \mathrm{~km}$ and the top of the subducted plate (OBH 55, Figure 8). Beneath the crest of the outer high, velocities gradually increase with depth, reaching values of $5.4-5.5 \mathrm{~km} / \mathrm{s}$ where the maximum thickness of $20 \mathrm{~km}$ of the outer high is observed. Lateral velocity changes are minimal between the present backstop structure and the crest of the outer high at CDP 17800 (OBH 60, Figure 12). However, a completely different velocity structure is recorded landward of the crest and beneath the forearc basin. Increasing deformation suggested by the MCS data is coincident with laterally increasing velocities in the lower part of the outer high. The strong lateral increase in velocities from the crest of the outer high to the forearc basin which is seen in the blowup in Figure 5 is documented by $\mathrm{OBH} 59$ (Figure 11). The upper sedimentary units (Psed1 and Psed2) show velocities of up to $4.7 \mathrm{~km} / \mathrm{s}$. The next layer displays velocities increasing from 5.5 to $7.2 \mathrm{~km} / \mathrm{s}$. This is established in the transition between phases Psed 2 and Plac-oc ${ }_{\text {up }}$ of $\mathrm{OBH} 59$, where the lower velocities of phase Psed2 dominate up to a distance of a little less than $20 \mathrm{~km}$. Apparent velocities then increase between 20 and $25 \mathrm{~km}$ distance (Plac$\mathrm{oc}_{\mathrm{up}}$ ), before decreasing again. This apparent velocity decrease at larger offsets is caused by the forearc basin sediments $\left(\operatorname{Psed}_{\mathrm{fb}}\right)$, through which the rays travel before hitting the surface. These characteristics in the ray paths are also evident in neighboring stations 58 and 60 (Figures 10 and 12). About $4 \mathrm{~km}$ of sedimentary fill is recorded in the forearc basin $\left(\operatorname{Psed}_{\mathrm{fb}}\right.$ of $\mathrm{OBH} 64$ in Figure 14 and MCS data (Figure 3b)), underlain by a $4-\mathrm{km}$-thick unit displaying velocities from 3.5 to $4.3 \mathrm{~km} / \mathrm{s}$. This unit is underlain by the aforementioned high-velocity layer with velocities between 5.5 and $7.2 \mathrm{~km} / \mathrm{s}$ (Figure 5blowup) as is documented by phases $\mathrm{Poc}_{\mathrm{up}}$ (e.g., OBH 64 in Figure 14 or OBH 66 in Figure 15; $\mathrm{Po}_{\text {up }}$ indicates refracted waves through this oceanic type crust of the upper plate). Velocities of this layer increase laterally toward the Javanese shelf, where they reach velocities of $5.9 \mathrm{~km} / \mathrm{s}$ at $5 \mathrm{~km}$ depth in the shelf. The shelf top appears as refracted phase $P_{\text {shelf }}$ and its corresponding nearvertical reflection (e.g., OBH 66 in Figure 15; also compare results from strike line SO138-06). The lower boundary beneath the shelf and forearc basin is characterized by a velocity step from 7.2 to $\sim 8.0 \mathrm{~km} / \mathrm{s}$, as can be deduced from the critical angle $i_{\text {crit }}$ of wideangle reflections $P m P_{\text {up }}$ recorded by OBH stations 60-62 (Figures 12,9 , and $13, P m P_{\text {up }}$ for upper plate Moho reflection). Station 64 (Figure 14) records this event beneath the forearc basin as a reflection $\left(P m P_{\text {up }}\right)$. Reversed coverage is achieved by OBS 66 (Figure 15) and OBH 67 (not shown) which recorded a strong $P m P_{\text {up }}$ at $15-16 \mathrm{~km}$ depth. The landward continuation of the mantle transition of the upper plate beneath the Java shelf at $\sim 15$ $\mathrm{km}$ depth is validated by strike line SO138-06.

\subsection{OBH Profiles SO138-06 and SO138-07}

[19] Wide-angle data were recorded along two strike lines to yield some 3-D constraints on the dip line (Figure 2) and are supplemented by ministreamer reflection data recordings (not shown here) [Flueh and Shipboard Science Party, 1999]. Profile SO138-07 is located $93 \mathrm{~km}$ landward of the deformation front along the crest of the outer high. The line shows a very smooth velocity structure along the outer high with little topography variation along strike. A sediment cover of $\sim 1 \mathrm{~km}$ thickness is present above the top basement, which was also observed on the dip line. Along this strike line, the topography of the top basement is much smoother compared to the dip line. No distinct basins or ponded sediments are visible in the ministreamer data. The deeper structure is characterized by fairly low velocities. Figure 16 shows data from station 78 , which recorded phases to a distance of almost $80 \mathrm{~km}$ and thus covers almost the complete line. Reverberations of more than $1 \mathrm{~s}$ caused by the sedimentary strata are characteristic of all stations, so that later events might be covered by this energy. Events Psed2 and Plac are present on all stations deployed along this profile, displaying velocities which increase from $4.1 \mathrm{~km} / \mathrm{s}$ in the upper segments to $5.4 \mathrm{~km} / \mathrm{s}$ at $20 \mathrm{~km}$ depth. While Psed 2 was also clearly recorded as a near-vertical reflection, the corresponding phase for Plac is not as apparent in the primary recording but is clearly visible in the multiple (Plac-mul in Figure 16). Several stations along this profile $(\mathrm{OBH} 78-81$ and $\mathrm{OBH} 86)$ recorded the top of the subducted oceanic plate. It is well imaged on the wideangle record section of OBH 78 (Figure 16) as refracted wave Poc at offsets greater than $-50 \mathrm{~km}$. The corresponding near-vertical reflection Ptoc is less apparent, and its onset is not as clearly defined.

[20] Profile SO138-06 is located at a distance of $180 \mathrm{~km}$ landward of the deformation front (Figure 2). Energy penetration on this line is limited, but the velocity structure to $\sim 20 \mathrm{~km}$ depth is resolved (Figure 5). The data quality of the later arrivals are somewhat poorer than on the other two profiles due to a lower signal-to-noise ratio, which might have been caused by heavier ship traffic or a different current pattern close to shore. The seafloor shows some topography expressed in a trough at the eastern end of the profile. The central part of the line lies in a broad, shallow basin above the Java shelf (Figure 5). OBH 74 is positioned near the center of this basin (Figure 17). A maximum of $3 \mathrm{~km}$ sediment cover is resolved in the basin, which is consistent with the ministreamer recordings, which resolve $\sim 1.4 \mathrm{~s}$ TWT of sediment fill [Flueh and Shipboard Science Party, 1999]. The Java shelf is traced beneath the basin by refracted phases $P_{\text {shelf }}$. The very clear vertical reflection (Figure 17) from the shelf top is compatible with 

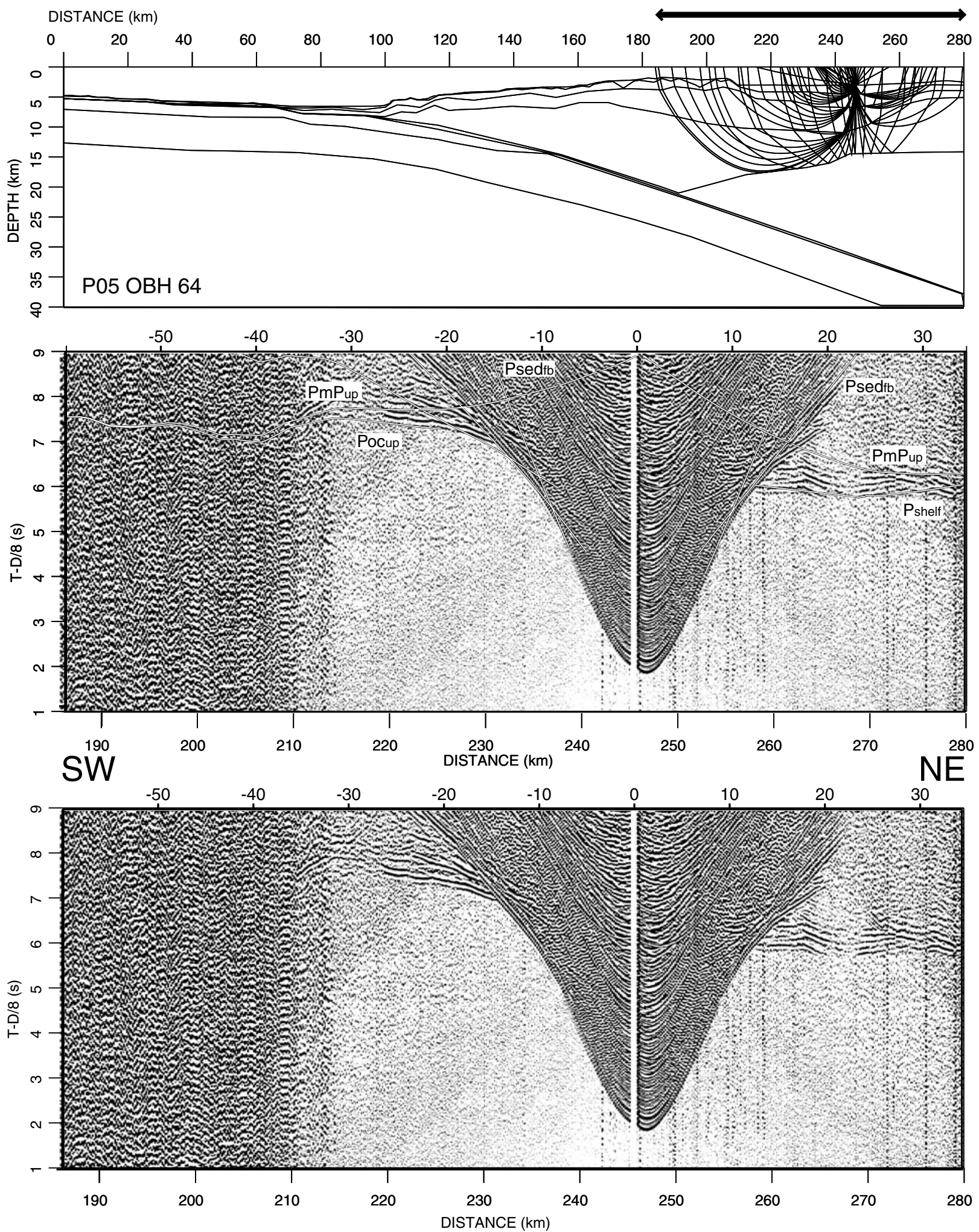

Figure 14. OBH 64, positioned in the center of the forearc basin. For further display information, see Figure 8. Phases Psed $_{\mathrm{fb}}$ denote refracted waves through the forearc basin sediment fill. Phase Poc $_{\mathrm{up}}$ documents the oceanic-type crustal layer beneath the basin, while $P_{\text {shelf }}$ travels through the shelf onset. Reflections $P m P_{\text {up }}$ mark the upper plate Moho beneath the forearc basin. 

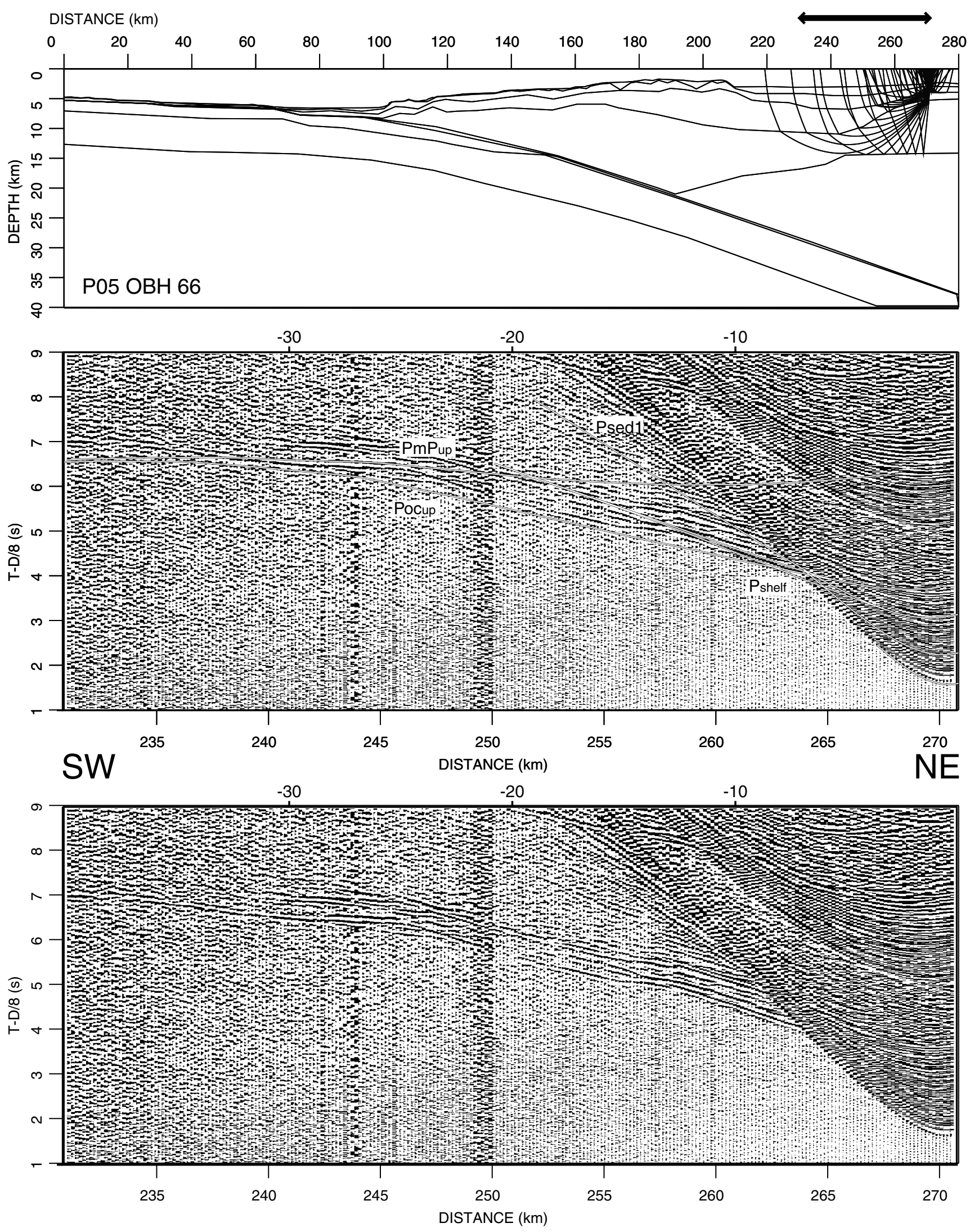

Figure 15. OBH 66, located on the Java shelf near strike line SO138-06. For further display information, please refer to Figure 8. Phase $\mathrm{Poc}_{\text {up }}$ travels through the oceanic-type crustal layer beneath the basin, and $P_{\text {shelf }}$ travels through the shelf onset. Reflection $P m P_{\text {up }}$ records the upper plate Moho. 

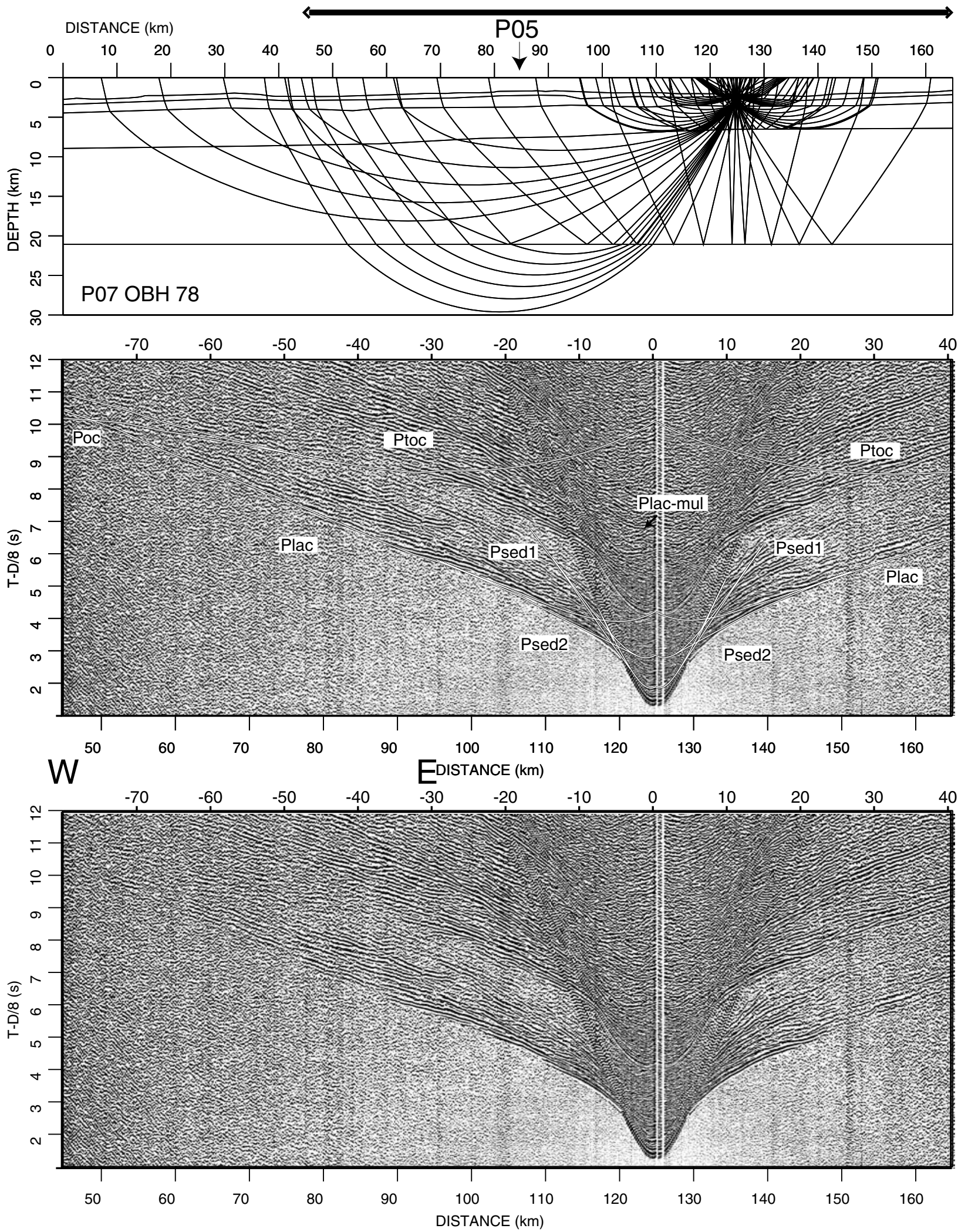

Figure 16. Ray paths and seismic section for $\mathrm{OBH}$ 78. For further display information, see Figure 8 . This is the easternmost station along strike line SO138-07 which runs along the crest of the outer high. The fairly low velocities of the outer high are validated by arrivals Psed 2 and Plac, which can be traced to offsets over $70 \mathrm{~km}$. Reflection Ptoc from the top of the subducted igneous crust yields some 3-D constraint on the dip of the subducted slab. 

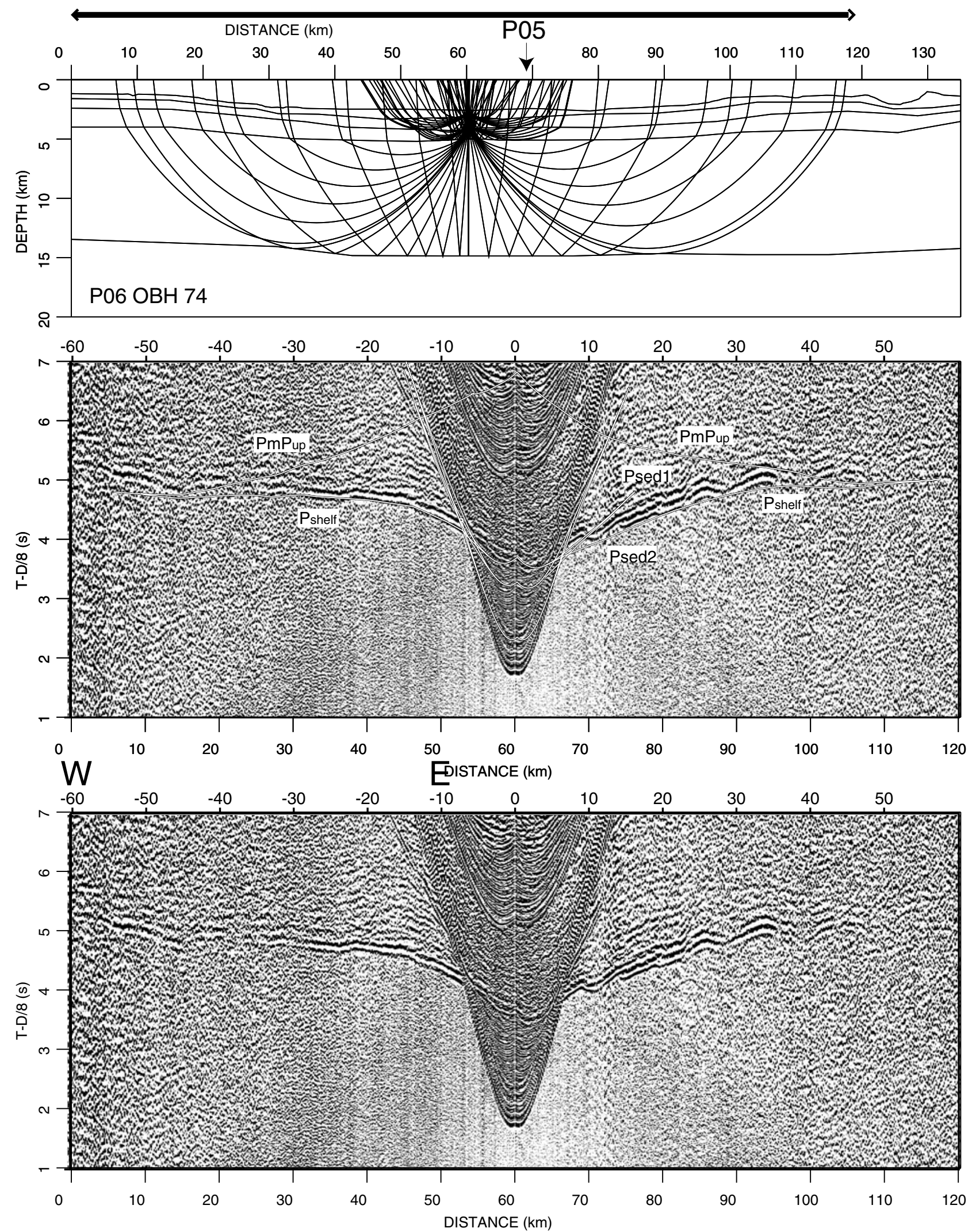

Figure 17. OBH 74, located near the center of strike line SO138-06 on the Java shelf. For further display information, please refer to Figure 8 . Phases $P_{\text {shelf }}$ travel through the shelf basement and show velocities of $\sim 6-7 \mathrm{~km} /$ $\mathrm{s}$. The corresponding near-vertical reflection at $3.8 \mathrm{~s}$ is also recorded along the dip line by the stations located on the Java shelf (compare OBH 66 in Figure 15). The weak $P m P_{\text {up }}$ yields some constraint on the extent of the upper plate Moho beneath the shelf onset. 

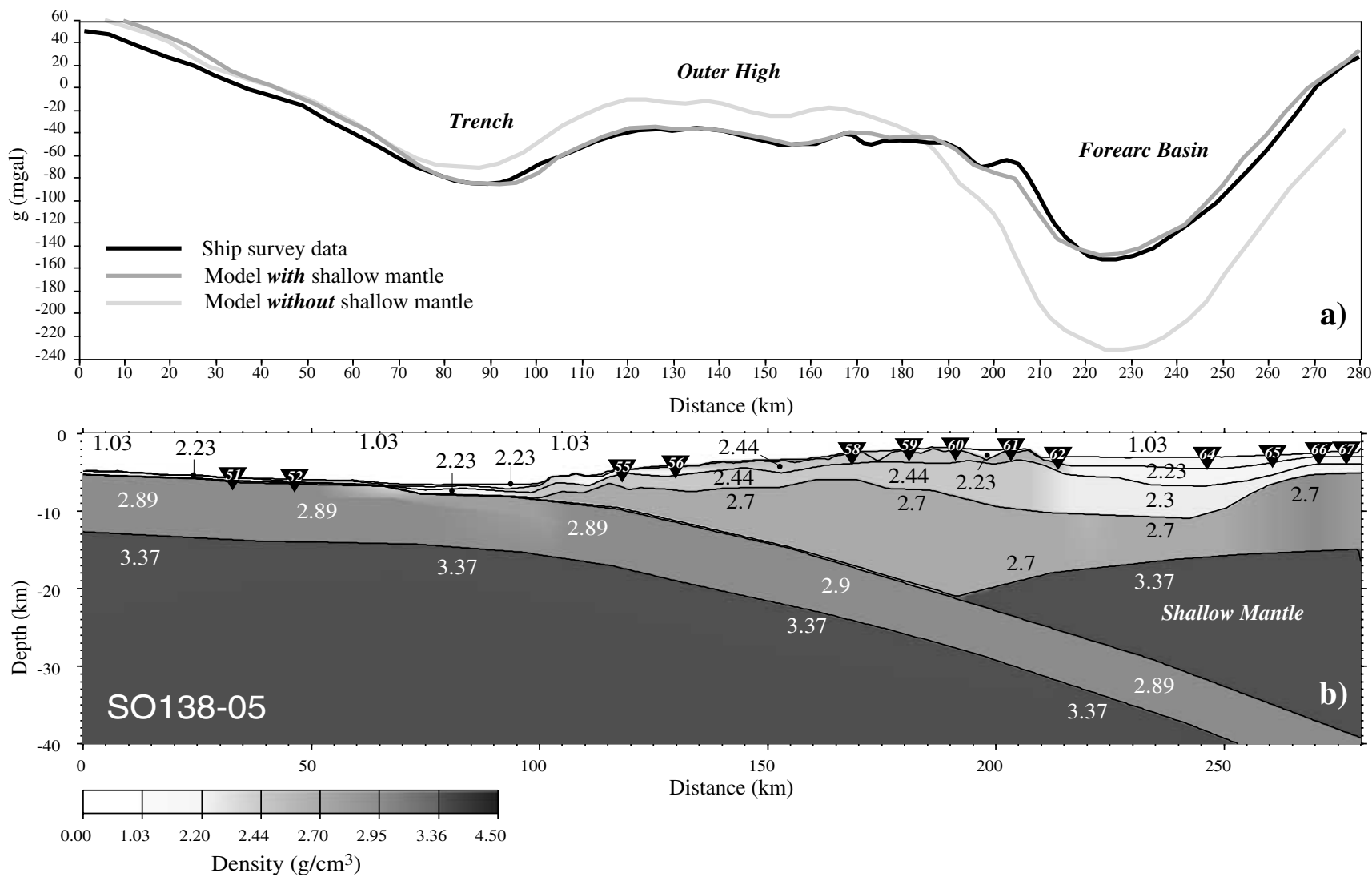

Figure 18. (b) Gravity model for dip line SO138-05. Density values were assigned to the velocity structures gained from forward modeling of the OBH data. (a) Resulting gravity anomaly (solid line) compared to ship data acquired during cruise SO138 [Heyde et al., 2000] (thick shaded line). The gravity calculations support the existence of a shallow mantle beneath the forearc basin. Without a shallow mantle, gravity discrepancies (thin shaded line in Figure 18a) of up to $90 \mathrm{mGal}$ are observed.

results from the dip line (e.g., OBH 66 in Figure 15). The crust beneath the shelf has a thickness of $\sim 10 \mathrm{~km}$ (Figure 5). Here, velocities increase from 5.9 to $7.2 \mathrm{~km} / \mathrm{s}$. A weak $P m P_{\text {up }}$ documents a shallow Moho at $15 \mathrm{~km}$ depth, which is in accordance with the dip line (Figure 17).

\subsection{Gravity Modeling}

[21] Further constraints on the velocity-depth model are provided by gravity modeling of the dip line SO138-05. The free-air gravity model (Figure 18b) was developed from a priori information of the tectonic structures obtained by the velocity-depth model (Figure 5). This information on the lateral extent of the main geological units is crucial due to the nonuniqueness of gravity models. The calculated gravity anomaly is compared to ship data acquired by the Bundesanstalt für Geowissenschaften und Rohstoff (BGR) during cruise SO138 (solid line in Figure 18a) [Heyde et al., 2000]. Gravity variations of up to $210 \mathrm{mGal}$ occur along the profile. The trench and the forearc basin are characterized by distinct

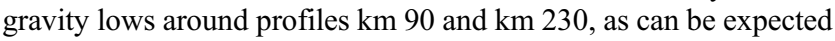
from the great depth of the trench and the sedimentary fill of the forearc basin, respectively. Our preferred model (dark shaded line in Figure 18a) fits the observed gravity response (solid line in Figure 18a) to within $\pm 10 \mathrm{mGal}$ along the whole profile, and thus, to firstorder approximation, the 2-D modeling corresponds adequately to the observed gravity values along the dip line. Without further efforts to ensure an overall superior fit a detailed match was nonetheless achieved except for the southwestern $30 \mathrm{~km}$ of the profile, where the observed gravity data are somewhat lower than the calculated response. The selection of density values which were assigned to the geological structures is based on the relationship between compressional velocities and densities and follows earlier studies [Kopp et al., 2001]. Density values between 2.23 and $2.44 \mathrm{~g} /$ $\mathrm{cm}^{3}$ [Ludwig et al., 1970] were used for the sedimentary strata (Figure 18b). The subducted crust was modeled with a uniform density of $2.89 \mathrm{~g} / \mathrm{cm}^{3}$ as proposed by Carlson and Raskin [1984]. Density values of $3.37 \mathrm{~g} / \mathrm{cm}^{3}$ as assigned to the underlying mantle are associated with the $\sim 90$-Myr-old lithosphere. As no drilling information on the composition of the outer high is available, the deeper segments of the outer high and frontal prism were assumed to have density values of $2.7 \mathrm{~g} / \mathrm{cm}^{3}$. These higher values are consistent with the greater overburden here. Assumed mantle densities of $3.37 \mathrm{~g} / \mathrm{cm}^{3}$ yield a good fit for the oceanic mantle beneath the igneous oceanic plate and thus were also assumed for the high-velocity material observed beneath the forearc basin where a satisfactory fit is observed. Removing this shallow mantle material and replacing it with densities typical of compacted or metamorphosed sediment of $2.7 \mathrm{~g} / \mathrm{cm}^{3}$ as found beneath the Java shelf causes a misfit of up to $90 \mathrm{mGal}$ (light shaded line in Figure 18a). This misfit is too large to be compensated by variations in the density structure of the upper segments or to be caused by 3-D effects. Thus the gravity data favor the presence of mantle material beneath the forearc basin and a shallow upper plate Moho here.

\section{Discussion}

\subsection{Oceanic Crust}

[22] The velocity-depth function of the incoming igneous crust along profile SO138-05 shows a normal velocity-depth 


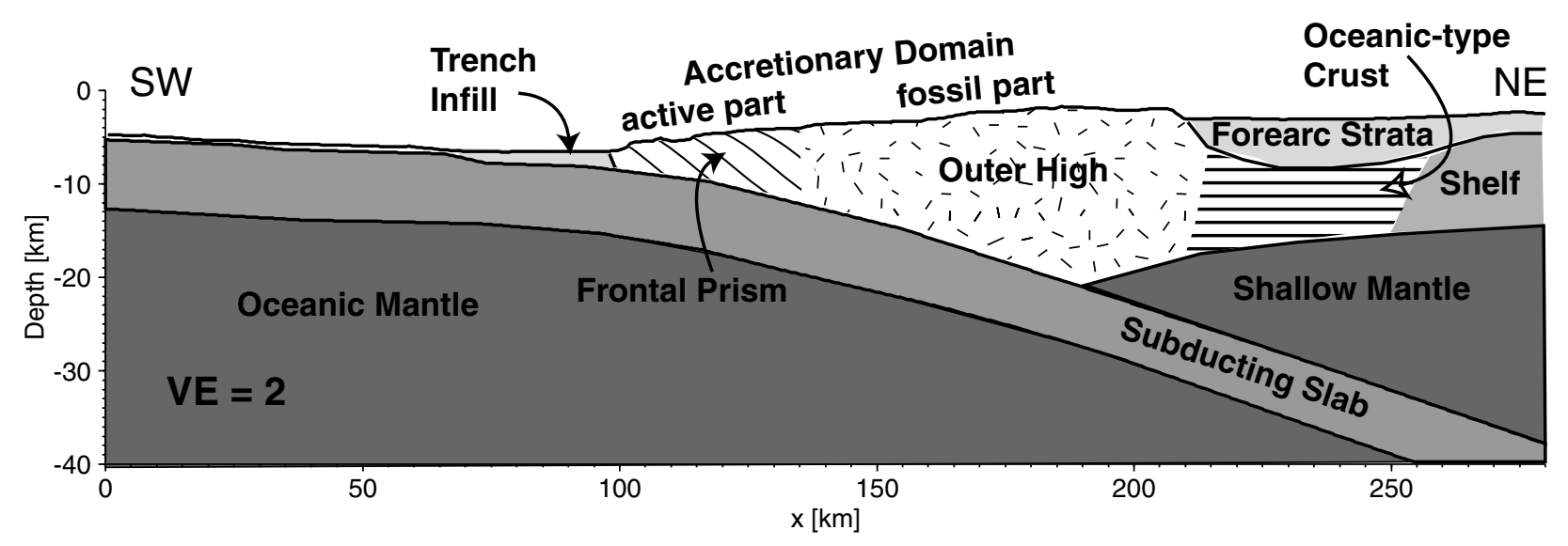

Figure 19. Major tectonic units of the Sunda margin. The accretionary prism between the deformation front and the forearc basin is composed of an active accretionary domain forming a frontal prism and the fossil accretionary domain of the outer high. The active and fossil parts of the accretionary domain are separated by the present backstop structure identified in the MCS data and a corresponding slope break. The shallow mantle beneath the forearc basin is validated by wide-angle seismic data and gravity modeling. It underlies a layer of elevated velocities which is interpreted as altered oceanic-type crust. Toward Java, the shelf onset is covered by coincident profiles SO138-05 and MCS line SO137-03 as well as strike line 06.

structure comparable with Pacific oceanic crustal samples older than 29 Ma [White et al., 1992]. Deep Sea Drilling Project (DSDP) Hole 211 at $9.78^{\circ} \mathrm{S}$ and $102.7^{\circ} \mathrm{E}$ south of southern Sumatra drilled Quaternary and Pliocene pelagic sediment and reached basement. As no $P n$ was recorded by the stations located on the ocean basin, the mantle velocity is assumed to be $8.0-8.1 \mathrm{~km} / \mathrm{s}$, in agreement with data collected off central Java [Curray et al., 1977], which show a similar structure of the oceanic crust and mantle seaward of the trench. Line MCS SO137-03 recorded a $1 \mathrm{~s}$ TWT thick sedimentary wedge in the trench which corresponds to $1.5-\mathrm{km}$ sediment thickness derived from the $\mathrm{OBH}$ data (Figure 6). Trench fill along Java varies considerably and is highest off western Java, where sediment influx to the oceanic plate has been influenced by the Bengal fan [Moore et al., 1980]. Some turbidite fill originating from axial sediment transport is resolved in the data. This material may have been transported over hundreds of kilometers along the Sumatra-Java trench system. Near the deformation front the trench fill is already affected by minor deformation and uplift as the sediments are pushed toward the toe of the accretionary wedge.

[23] As the crust enters the trench, it starts bending gently by $\sim 3^{\circ}$ (Figure 19). The top of the subducted plate is traced by a number of stations as its dip increases beneath the outer high to $7^{\circ}$. Strike line SO138-07 along the crest of the outer high yields some 3 -D constraint on the position of the slab as it is imaged at $21 \mathrm{~km}$ depth. As no local earthquake or tomographic studies exist, the slab configuration can only be correlated to global data, whose locations, however, are not detailed enough in this area to yield any conclusive information. From beneath the deformation front to at least $50 \mathrm{~km}$ beneath the accretionary prism an intracrustal reflector is recognized (Figure 3a) and interpreted as the upper to lower crust transition (Figure 5). Seaward of the deformation front and at greater depth this reflection is not well constrained as it is not resolved here.

\subsection{Structure of the Accretionary Domain}

[24] The active accretionary domain is defined as the seawardmost forearc material which is actively deformed at present between the deformation front and the slope break (Figure 19). A strong backstop reflection separates the active accretionary unit from the older accreted material of the outer high which composes the fossil part of the accretionary domain. Geomor- phologically, the active accretionary domain is characterized by a series of bathymetric highs, the most pronounced being the distinct ridge just landward of the deformation front (CDPs 10800-11700) (Figure 3a). This ridge displays a quite chaotic seismic character, indicating that some deformation and tectonic activity is currently occurring at the toe of the accretionary prism. Several imbricate thrust faults are recognized, most of which cut the seafloor and are still active. As the trench fill sediments are accreted and underthrust beneath this accretionary ridge, uplift is expressed in intense faulting. It remains unclear how much sediment is transported in a bypass channel beyond the present backstop structure; however, judging from the MCS data, the greater part is certainly frontally accreted. We interpret the frontal prism as evidence for ongoing accretion, resulting in the variable seafloor topography of accretionary ridges and a high degree of deformation and faulting. The velocity model supports this interpretation as lateral velocity changes occur up to the location of the present backstop structure. The fairly low $(<4.6 \mathrm{~km} / \mathrm{s})$ velocities are representative of young accreted sediment.

[25] A different situation emerges landward of the slope break. Tectonic activity in the seaward part of the outer high is less pronounced compared to that of the active accretionary domain. Velocities show little lateral variation but increase moderately with depth $(<5.5 \mathrm{~km} / \mathrm{s})$ due to material compaction. These velocities are supported by the results of strike line SO138-07 and are roughly in accordance with existing refraction data from central Java [Curray et al., 1977]. As no drilling information is available for the Java subduction complex (the closest drill holes are located within Sunda Strait on the Java shelf), the material constitution of the outer high basement is not known. Our velocity results indicate a sedimentary composition, possibly metamorphosed near the base; however, drilling information is needed to justify this assumption.

[26] Whereas the seaward part of the outer high shows little evidence of deformation, the landward part toward the forearc basin is experiencing ongoing activity. Several large pristine faults are recognized (e.g., around CDP 17800 or CDP 18400), which affect the seafloor. The top basement is more distinctly expressed toward the forearc domain, where its geomorphology forms several basins of increasing depth resulting from the steepening of the old accreted strata now forming the backstop. Sediment ponded in these basins is highly deformed. Folding involves the seafloor 
(e.g., around CDP 18800), and tectonic compressional activity is still ongoing.

\subsection{Forearc Domain}

[27] Compression also affects the seaward part of the forearc basin where folding of the entire sedimentary package causes a slight uplift of the seafloor. This remarkable pattern of large-scale folding and the pronounced unconformity at the outer high/ forearc basin transition compose the most striking aspect of the forearc basin structure. Landward of the depocenter, deformation of the sedimentary strata ceases. The nature of the outer high/ forearc transition remains open. Malod and Kemal [1996] propose that the dextral strike-slip movement along the Sumatra fault is relayed to the south by the Ujung Kulon Fracture Zone (Figure 1), which runs from the Sunda Strait transtensional basin [Lelgemann et al., 2000] along the northern transit of the outer high and fringes the forearc basin south of Java. Its southeastern extent is, however, not well established, and thus an interpretation of the outer high/forearc transition observed here as a strike-slip fault or continuation of the Ujung Kulon Fracture Zone, which is suggested by the seismic signal and the presence of the large basin, lies beyond the scope of this data set.

[28] The dip line covers the southwesternmost part of the Java shelf (Figure 19), which is composed of large downfaulted basement blocks rotated to the northeast. Existing multichannel data off central Java show a similar pattern [van der Werff, 1995]. Well data on the Java shelf north of Java island indicate that the shelf basement consists of late Oligocene volcanic rocks [Bolliger and De Ruiter, 1975]. Mesozoic-Paleogene mélange and intrusives related to an older active plate margin may also compose the basement [van der Werff, 1995]. The seismic layer beneath the forearc basin is a 5- to 7-km-thick unit with velocities increasing laterally toward the Java shelf. The higher velocities of the shelf correlate to the basement blocks, indicating a composition of metamorphosed pyroclastic sediment drilled in the Sunda Strait [Lelgemann et al., 2000]. Beneath the forearc basin, however, this unit is more oceanic in character with velocities increasing from 5.5 to $7.2 \mathrm{~km} / \mathrm{s}$. Similar results were reported off central Java [Curray et al., 1977], where a layer of variable velocity and thickness underlying the forearc basin is interpreted as altered oceanic crust. We favor an interpretation of this unit beneath the forearc basin as an oceanic-type crust (Figure 19). The base of this unit marks the crust-mantle boundary, as the seismic and gravity data support the existence of mantle material here (Figure 19).

[29] One possible explanation for oceanic-type crust positioned beneath the forearc basin would be to interpret it as remnant pieces of older oceanic crust. The subduction of the former Tethys ocean coincided with the opening of the Indian Ocean by rapid seafloor spreading during Cretaceous to middle Eocene times [Daly et al., 1991; Packham, 1996]. After the complete subduction of Tethys, incipient northward subduction of the Indian Ocean along the newly formed Sunda trench was initiated [Rangin and Pubellier, 1990], accompanied by a renewal of volcanic arc activity [Packham, 1996]. The Tethys suture zone, which crosses western Java [Rangin and Pubellier, 1990], represents the remaining fragment of this ocean and marks the trace of the subducted Tethys ocean. Without drilling and age information, however, an interpretation and evaluation of the oceanic crust found beneath the forearc basin cannot be well established and remains open.

\section{Conclusions}

[30] The combined analysis and interpretation of the wide-angle and reflection seismic data, together with the results of the 2-D gravity modeling, have allowed us to identify the major structural elements of the West Java margin at shallow and deep crustal levels (Figure 19). The structure of the subduction complex was resolved in detail by the reflection data, and together with the velocity information gained from the $\mathrm{OBH}$ data the following conclusions can be drawn:

1. The data clearly define a gently dipping Indian plate that subducts at $\sim 7^{\circ}$ beneath the outer high. The incoming igneous oceanic crust shows a thickness of $7.4 \mathrm{~km}$ and a velocity structure that lies within the range of values obtained for similar oceanic settings. The configuration of the descending slab is supported by the results of strike line SO138-07, which tracks the subducted plate at $21 \mathrm{~km}$ depth, and by the gravity modeling conducted along the dip line.

2. The seaward part of the margin is occupied by a $\sim 35-\mathrm{km}-$ wide and 7-km-deep active accretionary wedge. Accretion is ongoing, as is suggested by the intense pristine faulting and indicated by the existence of accretionary ridges in the frontal part of the margin. This is further supported by the velocity structure, which is characterized by low velocities $(4.6 \mathrm{~km} / \mathrm{s}$ at 7 $\mathrm{km}$ depth) and a positive lateral velocity gradient. The landward termination of the active accretionary domain is marked by a slope break and corresponding backstop structure, which represents a major structural break.

3. The massive outer high is $\sim 75 \mathrm{~km}$ wide and $20 \mathrm{~km}$ deep and represents the fossil part of the accretionary prism. Velocities are moderate beneath the outer high, displaying a downward positive gradient and reaching velocity values of 5.5 $\mathrm{km} / \mathrm{s}$ at $20 \mathrm{~km}$ depth. The material composition of the outer high is not known. The velocity model presented here makes an igneous or ophiolitic composition unlikely. A sedimentary composition, possibly containing metamorphosed material at its base, is consistent with the moderate velocities found here but would need to be justified by drilling information. The seaward part of the outer high shows little evidence for tectonic activity. The reflection data failed to resolve any details beneath the top basement. Deformation caused by compression increases toward the forearc basin and is expressed in intense folding of the ponded sediment on the outer high and of the forearc sediment fill. The cause of these compressional forces remains unexplained.

4. One crucial aspect of the study regards the nature of the forearc basement. A layer of elevated velocities was found beneath the forearc basin and shelf onset. Beneath the forearc basin the layer displays an oceanic-type velocity structure, whereas beneath the shelf the higher velocities $(>5.9 \mathrm{~km} / \mathrm{s})$ are attributed to rotated basement blocks of metamorphosed pyroclastic sediment which were identified in the MCS data. The base of this layer shows a velocity step from 7.2 to $\sim 8.0 \mathrm{~km} / \mathrm{s}$, as is deduced from the refracted waves through this segment and from the critical angle of the rays reflected from this boundary. The shallow upper plate Moho beneath the forearc basin is supported by the 2-D gravity modeling which expects highdensity material here. A possible source for oceanic-type crust might be remnant fragments of former oceanic crust that has been altered and might be related to the subduction of the former Tethys ocean. Drilling and age information as well as local earthquake data would help to further unravel the tectonic evolution of the margin.

[31] Acknowledgments. Special thanks go to Cpt. Papenhagen and the crew of R/V Sonne for their professional work and to the participants of the GINCO cruises for their help with data acquisition and preprocessing. We are grateful to C. Kopp for support during OBH modeling and data analysis. Discussions with C. Ranero and R. von Huene and comments by A. Kopf are kindly acknowledged. We thank R. L. Carlson and an anonymous referee for helpful review comments. We use the GMT software for many of the figures [Wessel and Smith, 1991]. The GINCO project is supported by the German Federal Ministry for Science and Technology (BMBF). 


\section{References}

Ben-Menahem, A., and W. B. Beydoun, Range of validity of seismic ray and beam methods in general inhomogeneous media, I, General theory, Geophys. J. R. Astron. Soc., 82, 207-234, 1985

Beydoun, W. B., and A. Ben-Menahem, Range of validity of seismic ray and beam methods in general inhomogeneous media, II, A canonical problem, Geophys. J. R. Astron. Soc., 82, 235-262, 1985.

Bolliger, W., and P. A. C. De Ruiter, Geology of the south central Java offshore area, Proc. Annu. Conv. Indones. Pet. Assoc., 4th, 67-82, 1975. Carlson, R. L., and G. S. Raskin, Density of the ocean crust, Nature, 311, 555-558,1984.

Červený, V., I. Molotkov, and I. Pšenčík, Ray Method in Seismology, Univ. of Karlova, Prague, Czech Republic, 1977.

Curray, J. R., G. G. Shor, R. W. Raitt, and M. Henry, Seismic refraction and reflection studies of crustal structure of the eastern Sunda and western Banda Arcs, J. Geophys. Res., 82, 2479-2489, 1977.

Daly, M. C., M. A. Cooper, I. Wilson, D. G. Smith, and B. G. D. Hooper, Cenozoic plate tectonics and basin evolution in Indonesia, Mar. Pet. Geol., 8, 2-21, 1991.

DeMets, C., R. G. Gordon, D. F. Argus, and S. Stein, Current plate motions, Geophys. J. Int., 101, 425-478, 1990.

Diament, M., C. Deplus, H. Harjono, M. Larue, O. Lassal, J. Dubois, and V. Renard, Extension in the Sunda Strait (Indonesia): A review of the Krakatau programme, Oceanol. Acta, 10, 31-42, 1990.

Flueh, E. R., and J. Bialas, A digital, high data capacity ocean bottom recorder for seismic investigations, Int. Underwater Syst. Design, 18, $18-20,1996$.

Flueh, E. R., and Shipboard Science Party, GINCO2 (Sonnecruise SO-138): Geo-scientific investigations along the active convergence zone between the eastern Eurasian and Indo-Australian plates off Indonesia, cruise report, GEOMAR, Kiel, Germany, 1999.

Hamilton, W., Tectonics of the Indonesian region, U.S. Geol. Surv. Prof. Pap., 1078, 1979.

Hamilton, W., Plate tectonics and island arcs, Geol. Soc. Am. Bull., 100, $1503-1527,1988$.

Heyde, I., H. A. Roeser, and B. Schreckenberger, Gravimetric measurements and their interpretation, GINCO Final Report, Part I, Bundesanst. für Geowiss. und Rohstof, Hannover, Germany, 2000.

Huchon, P., and X. Le Pichon, Sunda Strait and central Sumatra fault, Geology, 12, 668-672, 1984.

Izart, A., B. Mustafa Kemal, and J. A. Malod, Seismic stratigraphy and subsidence evolution of the northwest Sumatra fore-arc basin, Mar. Geol. 122, 109-124, 1994.

Karig, D. E., G. F. Moore, J. R. Curray, and M. B. Lawrence, Morphology and shallow structure of the lower trench slope off Nias Island, Sunda Arc, in The Tectonic and Geologic Evolution of Southeast Asian Seas and Islands, Geophys. Monogr. Ser, vol. 23, edited by D. E. Hayes, pp. 179208, AGU, Washington, D. C., 1980.

Kopp, H., E. R. Flueh, D. Klaeschen, J. Bialas, and C. Reichert, Crustal structure of the central Sunda margin at the onset of oblique subduction, Geophys. J. Int., 147, 449-474, 2001.

Lelgemann, H., M.-A. Gutscher, J. Bialas, E. R. Flueh, W. Weinrebe, and C. Reichert, Transtensional basins in the western Sunda Strait, Geophys. Res. Lett., 27, 3545-3548, 2000.

Ludwig, W. J., J. E. Nafe, and C. L. Drake, Seismic refraction, in The Sea, vol. 4, edited by A. E. Maxwell, pp. 53-84, Wiley-Interscience, New York, 1970.

Luetgert, J., MacRay-Interactive two-dimensional seismic raytracing for the Macintosh, U.S. Geol. Surv. Open File Rep., 92-356, 1992.

Malod, J. A., and B. M. Kemal, The Sumatra margin: Oblique subduction and lateral displacement of the accretionary prism, in Tectonic Evolution of Southeast Asia, edited by R. Hall and D. Blundell, Geol. Soc. Spec. Publ., 106, 19-28, 1996.

Malod, J. A., K. Karta, M. O. Beslier, and M. T. Zen Jr., From normal to oblique subduction: Tectonic relationships between Java and Sumatra, J. Southeast Asian Earth Sci., 12, 85-93, 1995.

McCaffrey, R., Oblique plate convergence, slip vectors, and forearc deformation, J. Geophys. Res., 97, 8905-8915, 1992.

Moore, G. F., J. R. Curray, D. G. Moore, and D. E. Karig, Variations in geologic structure along the Sunda forearc, Northeastern Indian Ocean, in The Tectonic and Geologic Evolution of Southeast Asian Seas and Islands, Geophys. Monogr. Ser., vol. 23, edited by D. E. Hayes, pp. 145160, AGU, Washington, D. C., 1980.

Packham, G., Cenozoic SE Asia: Reconstructing its aggregation and reorganization, in Tectonic Evolution of Southeast Asia, edited by R. Hall and D. Blundell, Geol. Soc. Spec. Publ., 106, 123-152, 1996.

Puspito, N. T., and K. Shimazaki, Mantle structure and seismotectonics of the Sunda and Banda arcs, Tectonophysics, 251, 215-228, 1995.

Rangin, C., and M. Pubellier, The quest for Tethys in the western Pacific, 8, Paleogeodynamic maps for Cenozoic time, Bull. Soc. Geol. Fr., 8, $907-$ 913, 1990.

Rangin, C., L. Jolivet, and M. Pubellier, A simple model for the tectonic evolution of Southeast Asia and Indonesia region for the past 43 m.y., Bull. Soc. Geol. Fr., 6, 889-905, 1990.

Reichert, C., and Shipboard Science Party, GINCO1 (Sonnecruise SO-137): Geo-scientific investigations along the active convergence zone between the eastern Eurasian and Indo-Australian plates off Indonesia, cruise report, Bundesanst. für Geowiss. und Rohstof, Hannover, Germany, 1999.

Samuel, M. A., and N. A. Harbury, The Mentawai fault zone and deformation of the Sumatran forearc in the Nias area, in Tectonic Evolution of Southeast Asia, edited by R. Hall and D. Blundell, Geol. Soc. Spec. Publ., 106, 337-351, 1996.

Tregoning, P., F. K. Brunner, Y. Bock, S. S. O. Puntodewo, R. McCaffrey, J. F. Genrich, E. Calais, J. Rais, and C. Subarya, First geodetic measurement of convergence across the Java trench, Geophys. Res. Lett., 21, 2135-2138, 1994.

van der Werff, W., Forearc development and early orogenesis along the Eastern Sunda/Western Banda arc (Indonesia), Ph.D. thesis, Vrije Univ., Amsterdam, 1995.

Wessel, P., and W. H. F. Smith, Free software helps map and display data, Eos Trans. $A G U, 72,441,445-446,1991$.

White, R. S., D. McKenzie, and R. K. O'Nions, Oceanic crustal thickness from seismic measurements and rare earth element inversions, J. Geophys. Res., 97, 19,681-19,715, 1992.

Widiyantoro, S., and R. van der Hilst, Structure and evolution of lithospheric slab beneath the Sunda Arc, Indonesia, Science, 271, 15661570, 1996.

Wilson, P., et al., Study provides data on active plate tectonics in Southeast Asia region, Eos Trans. AGU, 79(45), 545, 548-549, 1998.

J. Bialas, E. R. Flueh, D. Klaeschen, and H. Kopp, GEOMAR Research Center for Marine Geosciences, Wischhofstr. 1-3, D-24148 Kiel, Germany. (jbialas@geomar.de; eflueh@geomar.de; dklaeschen@geomar.de; hkopp@ geomar.de)

C. Reichert, Federal Institute for Geosciences and Natural Resources, BGR, Stilleweg 2, D-30655 Hannover, Germany. (christian.reichert@bgr.de) 